Revista IBERC

v. 4, n. 2, p. 79-111, maio/ago. 2021

www.responsabilidadecivil.org/revista-iberc

DOI: https://doi.org/10.37963/iberc.v3i2.160

\title{
RESPONSABILIDADE CIVIL E O EXERCÍCIO DAS LIBERDADES COMUNICATIVAS
}

CIVIL LIABILITY AND THE EXERCISE OF COMMUNICATIVE FREEDOMS

\section{Carlos Frederico Barbosa Bentivegna ${ }^{i}$}

RESUMO: O artigo trata da ponderação entre as liberdades comunicativas e a proteção aos direitos da personalidade, projetando as hipóteses de incidência da responsabilidade civil com a consideração da ilicitude do exercício da liberdade de manifestação do pensamento.

Palavras-chave: responsabilidade civil; liberdades comunicativas; direitos da personalidade.

\begin{abstract}
The article deals with the balance between communicative freedoms and the protection of the rights of the personality, projecting the hypotheses of incidence of civil liability with the consideration of the illegality of the exercise of freedom of expression of thought.
\end{abstract}

SUMÁRIO: 1. Introdução: o constante conflito potencial entre o exercício das liberdades comunicativas e a proteção da personalidade. 2. Direitos da Personalidade, Direitos Fundamentais e Liberdades Públicas. 3. Liberdades Comunicativas: Liberdade de Imprensa e Liberdade de Expressão e de Manifestação do Pensamento. 4. Colisão dos princípios constitucionais: liberdades comunicativas vs. proteção à personalidade. 4.1. Conflito de princípios constitucionais de mesma estatura. 5. Proposta de critérios para a ponderação entre os princípios em colisão aqui examinados. 5.1. Redução da esfera de proteção dos direitos da personalidade de pessoas ditas "pessoas públicas". 5.2. A vedação do discurso de ódio - "hate speech". 5.3. Direito ao esquecimento. 5.4. Animus jocandi - Si quis per jocum percuriat, injuriarum non tenetur. 5.5. Redução da esfera de proteção dos direitos da personalidade do criminoso ou do acusado do cometimento de crime. 6. Conclusão. Referências.

\section{INTRODUÇÃO: O CONSTANTE CONFLITO POTENCIAL ENTRE O EXERCÍCIO DAS LIBERDADES COMUNICATIVAS E A PROTEÇÃO DA PERSONALIDADE}

Atualmente, com o franco desenvolvimento da internet e da difusão "digital" de notícias e opiniões, nota-se significativo incremento no exercício das liberdades comunicativas - aí abarcadas a liberdade de imprensa, o direito à informação e a livre manifestação de opinião e das criações do

\footnotetext{
' Mestre em Direito Civil (2018), doutorando em Direito Civil (2019-) e graduado em Direito pela Faculdade de Direito da Universidade de São Paulo - USP em 1992, com especialização em Direito Privado; Especialização em Direito Processual Civil (1997) pelo Centro de Extensão Universitária do IICS. Advogado em São Paulo, sócio de Bentivegna Sociedade de Advogados. É membro titular do Instituto Brasileiro de Estudos de Responsabilidade Civil - IBERC. Foi Procurador-Geral do Município de Araçatuba/SP entre 2008 e 2011. Foi Chefe de Gabinete e, interinamente, Secretário dos Negócios Jurídicos do Município de São Paulo entre 2002 e 2003. Foi Gerente Jurídico da Companhia Metropolitana de Habitação de São Paulo - COHAB/SP entre 2001 e 2002. Foi advogado interno do Departamento Jurídico de BANESPA S/A Serviços Técnicos e Administrativos, ingressando em 1993. Advogou durante todo esse período, exceto nos momentos em que havia impedimento legal, nas áreas de Direito Civil e Direito Administrativo. Lecionou a disciplina Direito Civil em diversas instituições de ensino superior desde 1993 até o presente. E-mail: carlos@bradvs.com.br/ ORCID https://orcid.org/0000-0003-1404-6985
} 
intelecto. $\mathrm{O}$ acesso à difusão de ideias quedou-se facilitado e democratizado. Tal facilitação propiciou igualmente a ocorrência dos conflitos entre o exercício de tais liberdades e a preservação dos outros direitos da personalidade como a honra, a imagem e a privacidade. Não foi outra a conclusão a que chegou o estudioso da concentração dos meios de comunicação, André de Godoy Fernandes que afirma:

\begin{abstract}
A Internet, por ser uma mídia convergente, pulverizada e de livre acesso, tem a capacidade de promover a difusão de informações e dados que antes eram tradicionalmente transmitidos apenas por veículos de comunicação concentrados e setorizados (como televisão, rádio, jornal, revista). Na Internet, o acesso a diversos tipos de conteúdo (desde uma informação jornalística até eventos esportivos, filmes e músicas) é feito por um único meio convergente, aberto ao uso geral do público. É interessante destacar que a Internet permite ainda maior acesso por parte de indivíduos e organizações sociais a canais de comunicação com a sociedade. Blogs, wikis, web sites interativos, redes sociais e salas de discussão contribuem para maior diversidade e pluralismo de informação. A Internet facilita a comunicação na medida em que torna muito mais fácil e barata a distribuição da mensagem ou do conteúdo informativo. Podese afirmar que a Internet permite uma distribuição mais igualitária das oportunidades de participação na esfera pública". ${ }^{1}$
\end{abstract}

A facilitação do exercício das liberdades comunicativas permite, outrossim, a distribuição mais igualitária de (i) juízos de valor às vezes desfavoráveis sobre outrem, (ii) de notícias invasivas da esfera de privacidade de alguém, (iii) do uso indevido da imagem alheia etc. Em outras palavras: permite a maior difusão de eventuais agravos aos direitos da personalidade alheios, o que ocasionaria, em tese, a aplicação da responsabilidade civil no intuito de mitigar os danos experimentados.

Mas apenas mencionamos o incremento da difusão do pensamento através da rede mundial de computadores, não significando que queiramos a este ambiente nos ater. Tratamos, neste ponto, do abuso no exercício da liberdade de expressão e de manifestação do pensamento por qualquer meio: (i) numa "conversa de botequim"; (ii) através de noticiário televisivo de grande audiência; (iii) pela publicação de um livro ou uma obra de arte ou (iv) mediante qualquer outra via de comunicação de uma ideia.

É indisputável o fato de que a Constituição Federal brasileira garante a "quem quer que seja dizer o que quer que seja", na expressão sempre poética do ex Ministro do Supremo Tribunal Federal Carlos Ayres Britto, que também já chegou a afirmar que "a liberdade de expressão é a maior expressão da liberdade". Tal liberdade abrange a (i) exteriorização de suas impressões ou pensamentos, (ii) a exposição do fruto de sua atividade artística, intelectual, científica ou de comunicação e (iii) como corolário, o direito de informar e de ser informado sobre os fatos não abrangidos por uma causa legítima de sigilo. No entanto, essas prerrogativas não implicam na imunidade de seu titular em relação à resposta por eventual agravo a terceiros que o abuso desse direito venha a causar.

A Carta Magna garante ao cidadão um espaço apriorístico de movimentação: o uso de seu autorregramento privado para a exteriorização do pensamento e de toda a produção de seu espírito.

Eventual abuso no exercício desse direito - e o agravo que daí pode decorrer - são questões

\footnotetext{
1 FERNANDES, André de Godoy. Meios de comunicação social no Brasil: promoção do pluralismo, direito concorrencial e regulação. Tese de Doutorado sob orientação do Professor Doutor Calixto Salomão Filho, defendida perante a Faculdade de Direito da Universidade de São Paulo. São Paulo, 2009. p. 316.
} 
subsequentes e tratadas em dois incisos do mesmo artigo $5^{\circ}$ a disciplinar as garantias individuais: " $V$ é assegurado o direito de resposta, proporcional ao agravo, além da indenização por dano material, moral ou à imagem;" e "X - são invioláveis a intimidade, a vida privada, a honra e a imagem das pessoas, assegurado o direito à indenização pelo dano material ou moral decorrente de sua violação."

De clareza meridiana a premissa constitucional: não é pela possibilidade de agravo a terceiros, ou de abuso, que se vai coibir a primitiva liberdade de expressão. A liberdade de expressão é de ser plenamente garantida e livre de qualquer espécie de censura, dando margem a posteriori ao recurso de quem atingido por seu eventual exercício abusivo, ao direito de resposta ou à indenização dos danos materiais e mitigação dos danos morais dele decorrentes. É o binômio liberdade e responsabilidade. Salvo casos excepcionais autorizativos do recurso a medidas protetivas/preventivas (que com censura não se confundem), após realizada a ponderação entre os direitos conflitantes, como se verá adiante.

Em primeiro lugar tutela-se o direito subjetivo de o cidadão não sofrer impedimento ao utilizar de seu autorregramento privado - para usar a expressão de Pontes de Miranda, ao substituir a controversa expressão "autonomia da vontade" - para transmitir uma ideia, mensagem ou obra até então encerrada dentro de si para terceiros. É o momento de tirar algo da subjetividade e passar para o plano da ação e da socialização. Uma vez materializada essa escolha de manifestação do pensamento baseada no autorregramento privado de seu autor, realizou-se o direito subjetivo protegido pelo inciso IV do art. $5^{\circ}$ da CF/1988 e se exauriu de seu conteúdo. Esse direito, já exercido - apenas respeitados os limites trazidos pela própria constituição: anonimato, hate speech ${ }^{2}$ etc - em nada influi no direito subjetivo igualmente reconhecido àquele que, porventura possa ter sido agravado em sua honra, imagem, intimidade ou vida privada em face dessa utilização - ou abuso.

O outro dos direitos envolvidos, num ângulo diametral oposto, é o daquele que se sentiu agravado, portanto, de (i) exigir o direito de resposta e (ii) provar judicialmente a abusividade do exercício do direito do outro e, com isso, obter reparação dos danos que tenha experimentado.

Parece-nos, e de forma bastante clara, que a intenção da garantia fundamental insculpida no inciso VIII do art. $5^{\circ}$ da Constituição Federal não foi a de dar um salvo conduto ao achincalhe da honra, à invasão da privacidade ou à apropriação da imagem alheias. A mens legislatoris claramente teria sido proteger quem simplesmente manifesta suas convicções quer religiosas, quer filosóficas, quer políticas, sem vulnerar qualquer direito da personalidade alheio (como determinam o art. 220 e seu $\S 1^{\circ}$ ); ficando isento (pelo art. $5^{\circ}, \mathrm{VIII}$ ) de sofrer qualquer redução em seu arcabouço de direitos se, porventura, suas convicções forem contramajoritárias ou desagradem ao Estado.

Guillaume Lécuyer, em sua Tese de Doutorado ${ }^{3}$ defendida perante a Universitè PanthéonSorbonne (Paris I), intitulada "Libertè d'expression et responsabilité - Étude de droit privé", dizia que a liberdade de expressão é limitada pela existência de interesses vários que a Responsabilidade Civil

\footnotetext{
${ }^{2}$ Assunto de extrema importância, de que trataremos com maior profundidade adiante.

${ }^{3}$ LÉCUYER, Guillaume. Liberté d'expression et responsabilité - Étude de droit privé. Thèse pour le doctorat en droit de l'Université Panthéon-Sorbonne (Paris I). Paris: LGDJ, 2004, p. 153. Tradução livre de: "La définition de la responsabilité apparaît au centre d'une lutte d'influence entre l'intérêt de la liberté d'expression et les intérêts qu'elle malmène et qui sont digne de protection. Les limites de la liberté d'expression doivent être comprises comme formant la somme des résolucions de conflits d'intérêts, bien plus que comme l'édification d'interdits généraux".
} 
protege. A definição de responsabilidade, diz o autor em sua lúcida opinião, aparece no centro de uma luta de influência entre o interesse da liberdade de expressão e os interesses que ela maltrata e que são dignos de proteção. Os limites da liberdade de expressão devem ser entendidos como a soma dos conflitos de resolução de interesses, muito mais do que como a construção de proibições gerais.

\title{
2. DIREITOS DA PERSONALIDADE, DIREITOS FUNDAMENTAIS E LIBERDADES PÚBLICAS
}

Em que pese haver distinção estrutural entre os direitos privados da personalidade e os direitos públicos fundamentais, há muitos pontos de conexão entre eles e até momentos de sobreposição. Devemos, nós outros os intérpretes, encontrar os meios de relacioná-los, independentemente de sotoposição ou subordinação de um a outro (mas sim de coordenação), ou, no dizer preciso de José de Oliveira Ascensão4: "o progresso não está na absorção de um pelo outro, mas na sua coordenação em fórmulas sucessivamente mais perfeitas".

Segundo Capelo de Sousa5, "a afinidade emerge da parcial sobreposição ao nível da pessoa humana de dois planos jurídico-gnoseológicos: o de direito civil, onde se fundam os direitos de personalidade, e o de direito constitucional, donde irradiam os direitos fundamentais". Mas o autor adverte que, embora haja similitudes, não há perfeita coincidência entre uma coisa e outra e que, mesmo que muitos e diversos direitos de personalidade sejam também constitucionalmente reconhecidos como direitos fundamentais, nem todos o são; da mesma forma que nem todos os direitos fundamentais são direitos de personalidade - que dependem da concorrência de características muito especiais que os particularizam.

Neste ponto há que se citar trecho da autorizada e reveladora doutrina de Rabindranath Valentino Aleixo Capelo de Sousa, onde se lê:

\begin{abstract}
Esta larga coincidência entre os direitos de personalidade e os direitos fundamentais não significa assimilação ou perda de autonomia conceitual recíproca, pois tais categorias jurídicas, mesmo quando tenham por objeto idênticos bens de personalidade, revestem um sentido, uma função e um âmbito distintos, em cada um dos planos em que se inserem. Assim, as previsões do art. $70^{\circ}$ e segs. do Código Civil, referentes aos direitos de personalidade, valem apenas nas relações paritárias entre os particulares ou entre os particulares e o Estado destituído do seu ius imperii e são tuteladas através de mecanismos coercitivos juscivilísticos, v.g., em matéria de responsabilidade civil e de providências especiais preventivas ou reparadoras. Diferentemente, as previsões constitucionais relativas aos direitos fundamentais pressupõem, em primeira linha, relações publicísticas, de poder, são oponíveis ao próprio Estado, no exercício de seu ius imperii, embora também produzam efeitos nas relações entre os particulares, e têm mecanismos próprios de tutela constitucional, v.g., em matéria de conformação legislativa e administrativa, de declaração de inconstitucionalidade por acção ou omissão, de reserva relativa de competência legislativa e de delimitação de revisão constitucional. ${ }^{6}$ (grifos nossos)
\end{abstract}

Diz, em precioso artigo de sua lavra, Maurício Mazur acerca das similitudes e do afastamento

\footnotetext{
${ }^{4}$ ASCENSÃO, José de Oliveira. O direito: introdução e teoria geral - uma perspectiva luso-brasileira. Lisboa: Fundação Calouste Gulbenkian, 1977. p. 285.

5 CAPELO DE SOUSA, Rabindranath Valentino Aleixo. O direito geral de personalidade. Coimbra: Coimbra Editora, 1995. p. 581.

${ }^{6}$ Idem. p. 584.
} 
simultâneos entre os dois institutos:

mas a inegável atribuição histórica da tutela geral da personalidade ao direito civil não pode ser ignorada nem menosprezada numa investigação científica que se pretenda fiável. A origem dos direitos civis de personalidade remonta ao direito antigo grego e romano, enquanto que os direitos fundamentais tutelares de bens da personalidade são figuras jurídicas modernas. A tutela da personalidade pelo direito constitucional aproveita-se, nesse contexto, da longa evolução do direito civil. A fonte imediata dos direitos de personalidade é, inegavelmente, o Código Civil, não a Constituição. ${ }^{7}$

Pode-se afirmar, portanto, que o grande elemento de distinção entre os dois institutos é o locus onde tratados: pelo direito civil os direitos privados da personalidade e pelo direito constitucional os direitos públicos fundamentais. Esses últimos constituem-se em situações jurídicas dos particulares perante o Estado que, ao proteger poderes e esferas de liberdade de seus titulares, acabam por assegurar também alguns bens da personalidade.

Reconhecem-se, como já o dissemos, alguma sobreposição, embora não haja coincidência total entre uns e outros. Rabindranath Capelo de Souza ${ }^{8}$ adverte que, embora a Constituição Portuguesa tenha preordenado todo o ordenamento ao respeito à dignidade da pessoa humana, além de ter alargado a constitucionalização dos direitos da personalidade: nem todo direito da personalidade constitui direito fundamental e, do mesmo modo, nem todo direito fundamental é direito da personalidade.

Muitas são as consequências práticas da positivação constitucional dos direitos da personalidade, mas merecem destaque as quatro elencadas por Mazur, em virtude de sua intensidade: (i) tornam-se "realidades jurídicas operativas", abandonando o status de meras proposições políticas ou morais; (ii) passam a ser garantidos contra a eventual ingerência sobre seu conteúdo por parte do legislador infraconstitucional; (iii) "vinculam diretamente todos os poderes públicos" (parâmetro de decisões dos três poderes) e (iv) passam a dispor de "um conjunto de instrumentos sancionatórios que vão desde os mecanismos de fiscalização de constitucionalidade até a presença de meios específicos de tutela" constitucional. Mas o autor faz uma admoestação quanto à constitucionalização do direito civil, tendo-a por perigosa, nos seguintes termos:

A constitucionalização do direito civil é uma grave e recorrente ameaça à liberdade e à autonomia das relações privadas que se ampara na ideia equivocada de uma grande proximidade entre o direito civil e a Constituição. Ora, as garantias constitucionais apenas traduzem o reconhecimento estatal de uma ordem jurídico-privada, sem causar impacto autônomo em seu conteúdo. Nem mesmo o detalhado catálogo dos direitos fundamentais é capaz de criar uma ordem acabada e fechada que permita inferir a regulação civil. O primado material das relações privadas é todo do direito civil, que se distancia da constituição política e atua como um desenho da constituição social. ${ }^{9}$

\footnotetext{
${ }^{7}$ MAZUR, Maurício. A dicotomia entre os direitos de personalidade e os direitos fundamentais. In: MIRANDA, Jorge; RODRIGUES JUNIOR, Otávio Luiz; FRUET, Gustavo Bonato (orgs.). Direitos da Personalidade. São Paulo: Atlas, 2012. p. 26-27.

${ }^{8}$ CAPELO DE SOUZA, Rabindranath Valentino Aleixo. O direito geral de personalidade. Coimbra: Coimbra Editora, 1995. p. 30.

${ }_{9}^{9}$ MAZUR, Maurício. A dicotomia entre os direitos de personalidade e os direitos fundamentais. In: MIRANDA, Jorge; RODRIGUES JUNIOR, Otávio Luiz; FRUET, Gustavo Bonato (orgs.). Direitos da Personalidade. São Paulo: Atlas, 2012. p. 33.
} 
Com a finalidade de minorar o atrito causado a partir da aplicação das normas constitucionais sobre o direito civil, são necessárias algumas ações de adaptação, pois que a mera transposição de normas públicas para relações de direito privado sem qualquer clivagem gera efeitos indesejados como a publicização de relações entre particulares, impondo-lhes restrições originalmente pensadas para limitar a ação do Estado sobre o cidadão e não para limitar o autorregramento privado desse último.

Direitos fundamentais atuam, concretamente, tanto no âmbito privado quanto no público, gerando restrições, desde que, no entanto, observem certos limites balizadores dessa interação. Àquele que limitar voluntariamente um seu direito através de pacto no âmbito privado não é lícito, ao depois, invocar norma constitucional que venha a sobrepor-se a sua vontade livremente manifestada, no sentido de livrá-lo de alguma obrigação assumida. A não ser, é óbvio, que a limitação a direito fundamental tenha sido de tal monta que se tenha tornado incompatível com a essencialidade dos direitos da personalidade. É essa a operação de "harmonização" entre as normas constitucionais e aquelas de direito privado que se faz necessária sob pena de, no dizer de Mazur, "a vida jurídicoprivada, para além das incertezas derivadas do caráter muito genérico dos preceitos constitucionais", conhecer uma "extrema rigidez, inautenticidade e irrealismo"10.

\section{LIBERDADES COMUNICATIVAS: LIBERDADE DE IMPRENSA E LIBERDADE DE EXPRESSÃO E DE MANIFESTAÇÃO DO PENSAMENTO}

É necessário, em primeiro lugar, fazer uma advertência semântica. Sempre que mencionamos, a partir do título, e sempre que mencionarmos adiante Liberdades Comunicativas ou Liberdade de Expressão, o fazemos no sentido lato (lato sensu), que compreende, de forma ampla, a liberdade de manifestação do pensamento e da opinião (aí incluídas as produções do espírito, quer de natureza científica, literária, artística etc), bem como a liberdade de informação. Esta última, a liberdade de informação, no dizer do grande constitucionalista português Jorge Miranda ${ }^{11}$ também comporta suas subdivisões, identificando três momentos ou atitudes que se distinguem entre si: "o direito de informar corresponde a uma atitude ativa; o de se informar a uma atitude simultaneamente ativa e passiva (obter informação para si próprio); e o de ser informado, a uma atitude passiva ou receptiva (obter informação de outrem)".

É importante tal advertência porque há nuanças entre as diferentes modalidades da Liberdade de Expressão lato sensu. Por exemplo, para invocar a proteção da liberdade de informação o autor da afirmação que colida com direito alheio deve provar a verossimilhança da informação veiculada - não a verdade absoluta, que é inatingível -, algo que não se exige, em absoluto de quem invoca sua liberdade de expressão por ter emitido um juízo de valor sobre alguém através de manifestação artística, por exemplo.

\footnotetext{
${ }^{10}$ MAZUR, Maurício. A dicotomia entre os direitos de personalidade e os direitos fundamentais. In: MIRANDA, Jorge; RODRIGUES JUNIOR, Otávio Luiz; FRUET, Gustavo Bonato (orgs.). Direitos da Personalidade. São Paulo: Atlas, 2012. p. 43.

${ }^{11}$ MIRANDA, Jorge. Manual de direito constitucional: direitos fundamentais. Tomo IV. 2. ed. Coimbra: Coimbra Editora, 1993. p. 405 (nota de rodapé).
} 
Já dizia em 1857, sobre a liberdade de pensamento, o Marquês de São Vicente, José Antônio Pimenta Bueno, em sua obra "Direito Publico Brazileiro e Analyse da Constituição do Imperio":

a liberdade do pensamento em si mesmo, emquanto o homem não manifesta exteriormente, emquanto não o comunica, está fóra de todo o poder social, até então é do domínio sómente do próprio homem, de sua intelligencia e de Deos. A sociedade, ainda quando quizesse, não tinha meio algum de penetrar nessa esphera intellectual, suas leis não chegão até lá. ${ }^{12}$

Mais adiante, o tratar do pensamento manifestado, esse sim do interesse do mundo do Direito, diz o autor, verbis ${ }^{13}$ :

O homem porém não vive concentrado só em seu espírito, não vive isolado, por isso mesmo que por sua natureza é um ente social. Elle tem a viva tendencia e necessidade de expressar e trocar suas idéas e opiniões com os outros homens, de cultivar mútuas relações, seria mesmo impossível vedar porque fôra para isso necessario dissolver e prohibir a sociedade. Esta liberdade é pois um direito natural, é uma expressão da natureza intelligente do homem. É todavia necessario que o uso della não perca os caracteres de direito, não seja alterado pelas paixões, pelo crime, que não se dirija a fazer o mal"14.

A Constituição Federal de 1988 insculpiu em seus artigos 5, incisos IV, IX e XIV e artigo 220 os princípios da Liberdade de Expressão e Manifestação do Pensamento e da Liberdade de Informação (ou de Imprensa). Fê-lo, contudo, como também em relação a todos os outros direitos e garantias fundamentais, sem criar direito absoluto ou ilimitado.

Assim, trouxe, a par da garantia desses direitos e liberdades, as hipóteses de seu temperamento ante os eventuais danos causados às pessoas ou as exigências relativas às suas vidas privadas, honras e imagens ${ }^{15}$.

Infere-se muito claramente do texto constitucional que a liberdade de expressão e manifestação do pensamento e a liberdade de informação jornalística em que pese de enorme amplitude encontram único anteparo a partir do exato mesmo dispositivo constitucional que as introduz

12 PIMENTA BUENO, José Antônio. Direito publico brazileiro e analyse da constituição do imperio. Rio de Janeiro: Typ. Imp. e Const. de J. Villeneuve e C., 1857. p. 394.

13 Idem. p. 395.

${ }^{14}$ Mantida a grafia original do séc. XIX.

${ }^{15}$ Art. $5^{\circ}$. Todos são iguais perante a lei, sem distinção de qualquer natureza, garantindo-se aos brasileiros e aos estrangeiros residentes no País a inviolabilidade do direito à vida, à liberdade, à igualdade, à segurança e à propriedade, nos termos seguintes:

(...)

IV - é livre a manifestação do pensamento, sendo vedado o anonimato;

$(\ldots)$

IX - é livre a expressão da atividade intelectual, artística, científica e de comunicação, independentemente de censura ou licença;

$(\ldots)$

XIV - é assegurado a todos o acesso à informação e resguardado o sigilo da fonte, quando necessário ao exercício profissional.

Art. 220. A manifestação do pensamento, a criação, a expressão e a informação, sob qualquer forma, processo ou veículo não sofrerão qualquer restrição, observado o disposto nesta Constituição.

$\S 1^{\circ}$ Nenhuma lei conterá dispositivo que possa constituir embaraço à plena liberdade de informação jornalística em qualquer veículo de comunicação social, observado o disposto no art. $5^{\circ}$, IV, V, X, XIII e XIV.

$\S 2^{\circ}$ É vedada toda e qualquer censura de natureza política, ideológica e artística.

(...). 
na vedação do anonimato e na inviolabilidade da intimidade, da vida privada, da honra e da imagem das pessoas, assegurados o direito de resposta proporcional ao agravo e a indenização pelos danos materiais ou morais decorrentes de sua violação (incisos IV, $\mathrm{V}$ e X).

Em toda a história constitucional do Brasil a liberdade de expressão e manifestação do pensamento foi sempre garantida. Cada uma das Cartas Políticas brasileiras dedicou um dispositivo a garantir esse direito fundamental: a Constituição Política do Império do Brasil de 1824; a primeira Constituição republicana de 1891; a Constituição de 1934; aquela de 1937; a Constituição Federal de 1946; a Constituição de 1967 e EC Nº 1 de 1969 e a vigente Carta Constitucional, de 1988.

Desdobrando o conceito da liberdade de pensamento consagrada na Constituição Federal de 1988, leciona Pinto Ferreira ${ }^{16}$ que o sistema democrático e jurídico-constitucional da liberdade de pensamento é básico e desdobra-se das seguintes maneiras: a) liberdade de consciência, compreendendo a liberdade de crença (direito de professar qualquer religião ou de ser ateu) e a liberdade de opinião (ou o direito de possuir conviç̧ões próprias em matéria política ou filosófica); b) liberdade de exteriorização do pensamento, abrangendo a liberdade de culto (organização de movimentos religiosos, proselitismo, edificação de igreja e templo) e, além disso, a liberdade da palavra, imprensa, cátedra, ou aprendizagem científica, artística, literária.

Colhe-se do magistério de Paulo Gustavo Gonet Branco ${ }^{17}$, ao tratar do conteúdo da liberdade de expressão, que a garantia da liberdade de expressão tutela, ao menos enquanto não houver colisão com outros direitos fundamentais e com outros valores constitucionalmente estabelecidos "toda opinião, conviç̧ão, comentário, avaliação ou julgamento sobre qualquer assunto ou sobre qualquer pessoa, envolvendo tema de interesse público, ou não, de importância e de valor, ou não".

Até porque, "diferenciar entre opiniões valiosas ou sem valor é uma contradição num Estado baseado na concepção de uma democracia livre e pluralista" ${ }^{18}$.

\section{COLISÃO DOS PRINCÍPIOS CONSTITUCIONAIS: LIBERDADES COMUNICATIVAS VS. PROTEÇÃO À PERSONALIDADE}

Parece que a "euforia do Estado Principiológico" reconhecida por Humberto Ávila ${ }^{19}$ entre os constitucionalistas desbordou para outros ramos da ciência jurídica e veio dar no Direito Civil através do, já tão cantado em verso e prosa, fenômeno da "Constitucionalização do Direito Civil".

Mas o fenômeno objeto do presente estudo - a mitigação de dano moral em face de eventual abuso em alegado exercício das liberdades comunicativas - nasce e se resolve dentro da seara da responsabilidade civil. Trata-se de conflito típico do Direito Privado, mais especificamente do Direito Civil e conta com todo o seu arcabouço hermenêutico e com toda a sua principiologia para encontrar adequado deslinde.

${ }^{16}$ FERREIRA, Pinto. Comentários à Constituição brasileira. São Paulo: Saraiva, 1989. p. 70

17 MENDES, Gilmar Ferreira; BRANCO, Paulo Gustavo Gonet. Curso de direito constitucional. 11ªed, São Paulo: Saraiva. 2016. p. 264.

18 KARPEN, Ulrich. The Constitution of the Federal Republic of Germany, apud. MENDES, Gilmar Ferreira e BRANCO, Paulo Gustavo Gonet, Op. cit. p. 265.

19 ÁVILA, Humberto. Teoria dos princípios. 16. ed. revista e atualizada. São Paulo: Malheiros, 2015. p. 43. 
Segundo o magistério de Jorge Miranda, Otavio Luiz Rodrigues Junior e Gustavo Bonato Fruet, em seu erudito artigo "Principais problema dos direitos da personalidade e estado-da-arte da matéria no direito comparado" 20 , onde se faz uma veemente defesa do entendimento a que aderimos integralmente por sua perfeita logicidade, no sentido de que os direitos da personalidade, quer seja no ordenamento português (artigos $70^{\circ}$ a $81^{\circ}$ do Código Civil daquele país) quer no nosso (arts. 11 usque 21 do Código Civil de 2002), têm no Direito Civil o seu "âmbito normativo primário", vale dizer, as normas jusprivatísticas constantes do diploma civil dão as soluções de vinculação dos particulares, sendo despicienda a invocação constante do texto constitucional para o deslinde de questões a envolver direitos da personalidade. Dizem os autores:

O recurso imediato à dignidade humana como fundamento dos direitos da personalidade justifica-se no contexto da ordem jurídica alemã, dadas suas peculiaridades históricas. No caso brasileiro, porém, o Direito privado possui os elementos adequados à conformação normativa dos principais casos" (grifos nossos).

O tema pertence à jusprivatística, indisputavelmente, desde o seu surgimento, com a descrição da personalidade, seu início e fim, seus atributos; com a previsão de seus mecanismos de tutela e com todo o desenvolvimento hermenêutico do campo da responsabilidade civil para apurar eventual necessidade de satisfação da vítima de ataque a direito da personalidade.

Em sua tese de livre docência, depois publicada com o título "Direito Civil Contemporâneo Estatuto epistemológico, Constituição e direitos fundamentais" ${ }^{21}$, uma verdadeira trincheira da afirmação da autonomia epistemológica do Direito Civil e de resistência à tese de sua total "constitucionalização", Otavio Luiz Rodrigues Jr. afirmou que, em primeiro lugar, o princípio da supremacia hierárquica das normas constitucionais jamais foi desafiado no Brasil, sendo este um princípio aceito e sobre o qual escreveram se não todos, pelo menos a grande maioria dos civilistas pátrios, sempre reconhecendo a inconstitucionalidade, a não recepção ou a interpretação das normas de Direito Civil em conformidade com o disposto na Constituição Federal. Aduz o autor que "os autores mais antigos não usaram de expressões desenvolvidas na Teoria Constitucional alemã do segundo pós-guerra", mas diz também que mesmo eles nunca deixaram de reconhecer a supremacia hierárquica e a obrigatoriedade de adequação interpretativa. Prossegue o autor, a partir de sua pesquisa minuciosa e com a erudição que o marca, trazendo um saboroso exemplo dessa sua assertiva histórica:

Um exemplo extraído de obra do século XIX, embora reeditada no Novecentos, está na distinção do desforço possessório, prerrogativa conferida ao possuidor, que é esbulhado da coisa, de "tomá-la por sua própria força e autoridade, contanto que o faça em ato seguido". Em nota de rodapé, na mesma página, Lafayette Rodrigues Pereira, esclarece que esse conceito deriva das Ordenações (L.4, T, 58, § 2),

${ }^{20}$ MIRANDA, Jorge; RODRIGUES JUNIOR, Otávio Luiz; FRUET, Gustavo Bonato. Principais problemas dos direitos da personalidade e estado-da-arte da matéria no direito comparado, in Direitos da personalidade. MIRANDA, Jorge; RODRIGUES JUNIOR, Otávio Luiz; FRUET, Gustavo Bonato (orgs.). São Paulo: Ed. Atlas. 2012. p. 13.

${ }^{21}$ RODRIGUES JR., Otavio Luiz. Direito civil contemporâneo. Estatuto epistemológico, constituição e direitos fundamentais. Rio de Janeiro: Forense Universitária, 2019. p. 169. 
ressaltando que ele se aplica a todos os casos de desforço, "porquanto por incompatível com as teses fundamentais da nossa Constituição política, não prevalece mais a distinção que fazia a citada Ord. entre pessoas de pequena condição e fidalgos e cavalheiros para dar a estes maior espaço para o desforço".

O autor, contribuiu em muito para a desmistificação da doutrina que envolve a "Euforia a que se chamou Estado Principiológico" (para usar as palavras de Humberto Ávila, aqui já citadas), através da qual abandona-se, quase que completamente, uma hermenêutica multimilenar da privatística para que tudo se resolva com a aplicação de três ou quatro princípios alçados à estatura constitucional (para onde, fagocitado, teria também o Direito Civil sido levado). Pois bem, um dos pontos altos dessa contribuição de Otavio Luiz Rodrigues Jr. é, exatamente, a enumeração do quanto não seja operação de constitucionalização do direito civil: 1) a sobreinterpretação ou a reinterpretação de normas de Direito Civil (infraconstitucionais) conforme a C.F.; 2) a elevação do princípio da dignidade da pessoa humana à categoria de "elemento funcionalizante" do Direito Civil; 3) a consideração da Constituição Federal como centro do ordenamento jurídico; 4) o exercício de atos característicos da jurisdição constitucional, com o controle de constitucionalidade ou a interpretação das normas ordinárias conforme a Constituição; 5) utilização de cláusulas gerais e figuras típicas de "perturbação das prestações" (impossibilidade, mora, alteração da base negocial, violação positiva do contrato, culpa in contrahendo etc.) para a solução de controvérsias de Direito Privado, sem relação direta com a Constituição e 6) a "socialização", a "publicização" (no sentido do comunitarismo) e a atribuição de interpretação mais progressista ao Direito Civil22.

Estamos convencidos de que o deslinde dos conflitos que se estabelecem entre os direitos da personalidade com a consequente análise do cabimento de medidas preventivas, bem como daquelas mitigatórias de danos morais e indenizatórias dos danos materiais, são questões sotopostas ao âmbito do Direito Civil e sob suas normas deve o julgador se haver, embora tendo o cuidado de atentar para o caso de concorrência de proteção também constitucional ao valor protegido pela norma civil.

\subsection{Conflito de princípios constitucionais de mesma estatura}

A Constituição Federal e o Código Civil trazem uma série de princípios que formam entre si uma unidade coerente e harmônica em seu conjunto. Os princípios teriam, segundo afirma Edilsom Farias ${ }^{23}$, forte na lição de Canotilho, duas funções básicas: a) uma função hermenêutica, sendo úteis em primeiro lugar como elemento interpretativo que coadjuva no esclarecimento do real sentido de uma norma e b) uma função regulativa, sendo fonte de direito no caso de haver lacunas a ser preenchidas; nesta hipótese de funcionarem como elemento de colmatação de lacunas, os princípios seriam normas primárias a determinar diretamente a conduta de seus destinatários (papel de lex e não apenas de ratio legis).

22 RODRIGUES JR., Otavio Luiz. Direito civil contemporâneo, cit., p. 203.

${ }^{23}$ FARIAS, Edilsom Pereira de. Colisão de direitos. A honra, a intimidade, a vida privada e a imagem versus a liberdade de expressão e informação. Porto Alegre: Sergio Antonio Fabris Editor, 1996. p. 41. 
Haverá colisão, no entanto, entre os próprios direitos fundamentais (princípios) quando o exercício de um deles, por parte de um titular, conflita com o exercício do direito fundamental por parte de outro titular ${ }^{24}$, ou, noutros termos: "quando o Tatbestand (pressuposto de fato) de um direito interceptar o pressuposto de fato de outro direito fundamental" 25 .

Tais princípios, ao colidirem entre si, ao contrário do que ocorre quando há uma antinomia aparente entre normas legais - em que apenas uma deve ser declarada válida e a outra descartada (ou nem sempre, segundo a doutrina do Professor Humberto Ávila, que não confia nesse critério como um elemento distintivo fundamental entre regras e princípios) - devem passar por um processo de ponderação a partir da aplicação do princípio da proporcionalidade sobre o caso concreto com o fito de se verificar qual a preponderância verificável para aquela situação fática no cotejo entre as normas principiológicas conflitantes. Em outras palavras: o conflito entre princípios dessa estatura não pode levar senão à necessária conciliação entre eles, ao invés de determinar o aniquilamento do conteúdo de um ou outro.

No entanto, há, segundo esmiúça Gilmar Ferreira Mendes, em seu artigo "Colisão de Direitos Fundamentais: liberdade de expressão e de comunicação e direito à honra e à imagem"26, há uma reserva de lei qualificada que, para Edilsom de Farias ${ }^{27}$, consistiria numa fase prévia à técnica de resolução do conflito pelo juiz, sendo a resolução da colisão pelo legislador. O legislador deve disciplinar a Liberdade de Expressão e Informação - dado não ser direito absoluto - levando em conta os parâmetros (limites) impostos pelo $\S 1^{\circ}$ do art. 220, ou seja, a) proibindo o anonimato; b) oportunizando o direito de resposta e c) garantindo a inviolabilidade dos direitos à honra, à imagem, à intimidade e à vida privada das pessoas.

Agora já tratando da resolução da colisão pela jurisprudência Daniel Sarmento ${ }^{28}$ ressalta a necessidade de observância atenta do caso concreto para se determinar se se está efetivamente diante de um conflito entre princípios constitucionais: "A ponderação de interesses só se torna necessária quando, de fato, estiver caracterizada a colisão entre pelo menos dois princípios constitucionais incidentes sobre o caso concreto". Para o autor, portanto, a missão inicial que terá o intérprete, em face de uma hipótese de ponderação de princípios, será a de verificar se os comandos aparentemente colidentes efetivamente se confrontam na resolução do caso, ou se, ao contrário, é possível harmonizálos.

Robert Alexy ${ }^{29}$ explica a ponderação e diz que quanto maior é o grau de vulneração ou

\footnotetext{
${ }^{24}$ CANOTILHO, J.J. Gomes. Direito constitucional. 5. ed. Coimbra: Almedina, 1992. p. 657.

${ }^{25}$ FARIAS, Edilsom Pereira de. Colisão de direitos. A honra, a intimidade, a vida privada e a imagem versus a liberdade de expressão e informação. Porto Alegre: Sergio Antonio Fabris Editor, 1996. p. 93.

${ }^{26}$ MENDES, Gilmar Ferreira. Colisão de direitos fundamentais: liberdade de expressão e de comunicação e direito à honra e à imagem. in Informativo Consulex, ano VII, vol. 43, Brasília, 1993. p. 1.150.

${ }^{27}$ FARIAS, Edilsom Pereira de. Colisão de direitos. A honra, a intimidade, a vida privada e a imagem versus a liberdade de expressão e informação. Porto Alegre: Sergio Antonio Fabris Editor, 1996. p. 138.

28 SARMENTO, Daniel. A ponderação de interesses na constituição federal. Rio de Janeiro: Lumen Juris, 2002. p. 99.

${ }^{29}$ ALEXY, Robert. Teoría de los derechos fundamentales. Trad. Ernesto Garzón Valdéz. Madrid: Centro de Estudios Constitucionales, 1993. p. 161. No original: "El derecho de libertad del indivíduo se manifiesta [...] con tanta más fuerza, cuanto más se cuestiona su derecho a la libre elección de la profesión; la protección de la comunidad es tanto más urgente, cuanto mayores son los inconvenientes y peligros que pudieran resultar para la comunidad de una libertad total de ejercicio de la profesión". "Cuanto más afecte la intervención legal expresiones
} 
afetação de um princípio, maior tem de ser a importância da observância do outro princípio; isto é, um princípio deve sofrer limitações diretamente proporcionais à importância da obediência ao outro princípio com que colide: para ele, esta é a Lei da Ponderação.

Não resta dúvida que no caso em estudo - da disputa entre as liberdades comunicativas e a necessidade de "indenização" por dano moral oriundo de ofensa à personalidade - trata-se de uma colisão entre princípios constitucionais além de um conflito de Direito Privado atinente à responsabilidade civil e a técnica da ponderação é a melhor ferramenta a ser utilizada para a solução do problema. Novamente tomamos as palavras de Daniel Sarmento ${ }^{30}$ ao esmiuçar a técnica da ponderação de princípios: "tal método caracteriza-se pela sua preocupação com a análise do caso concreto em que eclodiu o conflito, pois as variáveis fáticas presentes no problema enfrentado afiguram-se determinantes para a atribuição do 'peso' específico a cada princípio em confronto, sendo, por consequência, essenciais à definição do resultado da ponderação".

O que deve se dar em face da colisão de princípios de igual estatura - um conflito real, portanto, e não uma antinomia aparente de normas - é a operação da "concordância prática" (ou Schonendsten Ausgleich para os alemães), que tão bem descreve Manuel da Costa Andrade ${ }^{31}$, dizendo que segundo ela as colisões entre direitos fundamentais não são de se solucionar de forma a que um deles reste sacrificado totalmente em benefício do outro. Ao invés disso, deve-se buscar garantir a ambos a mais completa eficácia e "a mais consistente proteção em concreto" possível. Isso se consegue com a salvaguarda do núcleo essencial do direito fundamental a ceder espaço, evitando-se um sacrifício desmesurado ou desproporcionado de seu conteúdo.

Mais adiante, segue o jurista português, amparando-se também nas lições de Degenhart:

entre a fenomenologia da conflitualidade precipitada pela projeção destes bens jurídicos no plano horizontal avulta sobremaneira a colisão com o exercício da liberdade de imprensa e a prossecução dos valores ou interesses a que aquele exercício anda invariavelmente associado. Isto tanto pela frequência destes conflitos como pela sua complexidade e relevo pragmático. De acordo, por exemplo, com Degenhart, é precisamente 'este conflito entre a tutela da personalidade e a liberdade de comunicação social que configura a constelação problemática de maior relevo prático no desenvolvimento dos direitos de personalidade, em geral'. ${ }^{32}$

Rabindranath Capelo de Sousa, em seu já clássico "O Direito Geral de Personalidade" explica que a multiplicidade e a complexidade das situações e relações, a que submetidas as pessoas de hoje em dia, são terreno fértil para que possa haver uma enorme gama de possibilidades fáctico-jurídicas sobre as quais incida o exercício do direito geral de personalidade ou dos direitos especiais de personalidade de uma certa pessoa; e para que estas possiblidades se sobreponham àquelas que

elementares de la libertad de acción humana, tanto más cuidadosamente tienen que ponderarse las razones presentadas para su fundamentación frente al derecho fundamental de libertad del ciudadano". "Además resulta que [...] la ponderación necesaria tiene, por una parte, que tener en cuenta la intensidad de la intervención en el ámbito de la personalidad a través de una emisión radial de este tipo; por otra, hay que evaluar el interés concreto a cuya satisfacción sirve la emisión y para la que es adecuada..."

${ }^{30}$ ALEXY, Robert. Teoría de los derechos fundamentales, cit., p.97-98.

31 ANDRADE, Manuel da Costa. Liberdade de imprensa e inviolabilidade pessoal - Uma perspectiva jurídicocriminal. Coimbra: Coimbra Editora, 1996. p. 34.

32 Idem. pp. 34-35. 
permitam o exercício de direitos alheios da mesma natureza. Isto é, situações em que se tornem inconciliáveis ou incompatíveis os exercícios do direito geral de personalidade, dos direitos especiais de personalidade ou de outro direito subjetivo por parte de diferentes pessoas. Assim, na hipótese de se estar diante de uma colisão real de direitos, segundo o autor, impõe-se a aplicação de técnica por ele detalhada em quatro etapas. De forma bastante resumida, pode-se citar o seguinte trecho explicativo de seu raciocínio:

Para Tanto, importa proceder a uma criteriosa identificação e ponderação quer dos bens jurídicos tutelados pelas normas jurídicas estruturantes dos direitos colidentes, quer dos conteúdos dos poderes jurídicos resultantes destes direitos, quer ainda dos factos reais constitutivos ou modificativos de cada um dos direitos subjectivados em colisão, das modalidades de actividade material concretamente exercitadas ou exercitandas pelas partes e dos interesses efectivamente prosseguidos pelas partes. Com efeito, tal ponderação, como bem refere HUBMANN, não pode ser exclusivamente feita mediante uma abstracta comparação de bens e valores jurídicos tutelados, pois depende também largamente da situação concreta.

Pormenorizemos. Em um dos pratos da balança, após verificarmos a existência real de ambos os direitos subjectivados em colisão e a inexistência de regulação legal específica para tal conflito, colocaremos todos os factos reais juridicamente relevantes e todos os valores jurídicos respeitantes, uns e outros, ao direito de personalidade concretamente conflituante. ${ }^{33}$

Interessantíssima é a reflexão produzida por Capelo de Sousa ${ }^{34}$ quanto à possibilidade de colisão entre dois direitos com estrutura formal e fundamento axiológico-normativo fundados em interesses concretos juridicamente tutelados: (i) de qualidade e grau idênticos ou (ii) de qualidade e grau diversos, mas de peso equilibrado, casos em que não haverá predominância do interesse de uma das partes; e quando não há tal identidade ou equilíbrio, casos em que preponderará "o interesse concreto de uma das partes por ponderação e avaliação jurídicas".

Os exemplos dados pelo jurista conimbrecense são os seguintes: 1) para o caso de qualidade e grau idênticos dos interesses tutelados - "duas pessoas com o mesmo nome que comecem simultaneamente a exercer a mesma profissão por conta própria na mesma povoação poderão ver-se envolvidas em conflitos relativos ao uso de tal nome, que terão de ser resolvidos numa base de igualdade dos direitos em presença”; 2) para o caso de mesma qualidade dos interesses tutelados, mas com diferentes graus - "que, face às respectivas ponderações e avaliações jurídicas aumentativas ou diminutivas, conduzam a um peso jurídico total desequilibrado de tais direitos entre si. Nestes termos, se o mesmo assento de um autocarro público for disputado simultaneamente por um invisual e por uma pessoa não deficiente, aquele tem preferência, pois, embora seja a mesma espécie de bem de personalidade tutelada, há um maior grau ou uma maior intensidade da tutela jurídica"; 3) para o caso de colisão de dois direitos de personalidade tendo por objeto diferentes espécies de bens de personalidade - "o destinatário de uma carta não confidencial não a pode publicar se isso prejudicar seriamente o autor" (ponderação e análise jurídica sempre levando em conta "o circunstancialismo factual juridicamente relevante em que se processou a subjetivação dos direitos de personalidade em

${ }^{33}$ CAPELO DE SOUSA, Rabindranath Valentino Aleixo. O direito geral de personalidade. Coimbra: Coimbra Editora, 1995. pp. 533 e ss.

${ }^{34}$ CAPELO DE SOUSA, Rabindranath Valentino Aleixo. O direito geral de personalidade, cit., pp. 543/547. 
conflito")

Entre os doutrinadores brasileiros, colhe-se a lição de Luís Roberto Barroso, para quem, de forma resumida, poder-se-ia descrever o processo de ponderação como algo que se desenvolve em três diferentes fases: a primeira delas envolve a detecção, por parte do intérprete, das normas relevantes para o deslinde do caso e a identificação de eventuais conflitos entre elas.

A segunda fase é o momento em que se examinam "os fatos, as circunstâncias concretas do caso e sua interação com os elementos normativos". Dessa forma, o exame do substrato fático e o efeito que sobre ele terão as normas individualizadas na primeira fase apontarão com facilidade o papel que cada uma delas terá e o seu grau de importância para a solução do caso concreto.

“É na terceira etapa que a ponderação irá singularizar-se, em oposição à subsunção". Nessa etapa crucial, voltada à tomada de decisão propriamente dita,

\begin{abstract}
os diferentes grupos de normas e a repercussão dos fatos do caso concreto estarão sendo examinados de forma conjunta, de modo a apurar os pesos que devem ser atribuídos aos diversos elementos em disputa e, portanto, o grupo de normas que deve preponderar no caso. Em seguida, é preciso ainda decidir quão intensamente esse grupo de normas - e a solução por ele indicada - deve prevalecer em detrimento dos demais, isto é: sendo possível graduar a intensidade da solução escolhida, cabe ainda decidir qual deve ser o grau apropriado em que a solução deve ser aplicada. Todo esse processo intelectual tem como fio condutor o princípio instrumental da proporcionalidade ou razoabilidade. ${ }^{35}$
\end{abstract}

Na mesma esteira, Gilmar Mendes ${ }^{36}$ trata com muita propriedade da questão da colisão de princípios constitucionais, trazendo, inclusive, a visão da Corte Constitucional Alemã quando o tema é a defesa do postulado da dignidade humana (Grundsatz der Menschenwurde) enquanto integrante dos princípios fundamentais da ordem constitucional (tragende Konstitutionsprinzipien): "fala-se em colisão entre direitos fundamentais quando se identifica conflito decorrente do exercício de direitos fundamentais por diferentes titulares. A colisão pode decorrer de conflito entre (a) direitos individuais, (b) direitos individuais e bens jurídicos da comunidade e (c) entre bens jurídicos coletivos”. Adverte-nos o autor, entretanto, que a ideia de conflito ou de colisão de direitos não é sempre que se verifica, pois nem tudo que se pratica alegando exercer regularmente um direito que estaria em colisão com outro, encontra abrigo no seu âmbito de proteção. "Assim, muitas questões tratadas como relações conflituosas de direito configuram conflitos aparentes, uma vez que as práticas controvertidas desbordam da proteção oferecida pelo direito fundamental em que se pretende buscar abrigo".

De fato, duas importantes arenas a abrigar a discussão teórica e prática quanto ao conflito aqui estudado e as possíveis técnicas de sua solução foram as cortes constitucionais alemã e norteamericana. Não à toa, portanto, têm-se como importante referencial doutrinário os trabalhos do alemão Robert Alexy e do estadunidense Ronald Dworkin.

Alexy reconhece uma conexão estreita entre a teoria dos princípios e a "máxima da proporcionalidade", que adviria, para o autor, do caráter lógico dos princípios. Por serem os princípios

35 BARROSO, Luís Roberto. A nova interpretação constitucional: ponderação, direitos fundamentais e relações privadas. 3. ed., Rio de Janeiro: Renovar, 2008, p. 346-348.

${ }^{36}$ MENDES, Gilmar Ferreira; BRANCO, Paulo Gustavo Gonet. Curso de Direito Constitucional. 11. ed. São Paulo: Saraiva, 2016. p. 234 e ss. 
mandados de otimização com relação às diversas possibilidades fático-jurídicas, implicaria sua natureza na "máxima da proporcionalidade", dividida, segundo o autor, em três diferentes níveis: 1) máxima da conformidade ou adequação dos meios (Geeignetheit); 2) da exigibilidade ou da necessidade (Erforderlichkeit - requisito do meio menos gravoso) e 3) da proporcionalidade stricto sensu (Verhältnismässigkeit). ${ }^{37}$ Para Edilsom Pereira de Faria38 "as máximas de adequação e da necessidade são deduzidas do caráter dos princípios como mandados de otimização referente às possibilidades fáticas; a máxima da proporcionalidade em sentido estrito ou mandado de ponderação refere-se às possibilidades jurídicas de realização dos princípios. Isto é, na hipótese de colisão de princípios, a efetivação dos mesmos dependerá dos princípios opostos, e a escolha dos que prevalecerão no caso concreto será conduzida pela ponderação dos princípios em jogo".

E, realmente, Ronald Dworkin, em seu “Levando os Direitos a Sério”39, ensina sobre a colisão de princípios que a diferença entre princípios jurídicos e regras jurídicas é de natureza lógica e que ambos orientariam escolhas particulares sobre obrigações jurídicas em casos concretos, embora diferindo quanto à natureza da orientação que oferecem. As regras têm uma aplicação radical que o autor denomina all ou nothing, ou seja "são aplicáveis à maneira do tudo-ou-nada". Diz ele: "dados os fatos que uma regra estipula, então ou a regra é válida, e neste caso a resposta que ela fornece deve ser aceita, ou não é válida, e neste caso, em nada contribui para a decisão".

Isso implica, segundo Dworkin, que os princípios trazem consigo uma outra característica, ou dimensão, inexistente entre as regras: "a dimensão do peso ou importância. Quando os princípios se intercruzam (por exemplo, a política de proteção dos compradores de automóveis se opõe aos princípios de liberdade de contrato), aquele que vai resolver o conflito tem de levar em conta a força relativa de cada um. Esta não pode ser, por certo, uma mensuração exata e o julgamento que determina que um princípio ou uma política particular é mais importante que outro", ou seja, é o exame do caso concreto e nenhuma norma abstrata que revelará o maior peso naquela circunstância fática.

Robert Alexy traz a seguinte advertência:

as colisões entre princípios devem ser solucionadas de forma completamente diversa [do conflito entre regras]. Se dois princípios colidem - o que ocorre, por exemplo, quando algo é proibido de acordo com um princípio e, de acordo com outro, permitido - um dos princípios terá que ceder. Isso não significa, contudo, nem que o princípio cedente deva ser declarado inválido, nem que nele deverá ser introduzida uma cláusula de exceção". Para o autor vale a regra mais rígida, posteriormente combatida por Humberto Ávila, no sentido de que o princípio nunca cede completamente e a regra sempre cede completamente (é declarada inválida). Para ele o que ocorre, invariavelmente, é que o princípio que obteve a precedência naquele processo de ponderação, teve maior peso sob aquelas condições. Em presença de outro substrato fático "a questão da precedência pode ser resolvida de forma oposta. Isso é o que se quer dizer quando se afirma que, nos casos concretos, os princípios têm pesos diferentes e que os princípios com o maior peso têm precedência. Conflitos entre regras ocorrem na dimensão da validade, enquanto as colisões entre princípios - visto que só princípios válidos podem colidir - ocorrem, para além dessa dimensão, na dimensão do

\footnotetext{
${ }^{37}$ ALEXY, Robert. Teoría de los derechos fundamentales, cit., p. 161

${ }^{38}$ FARIAS, Edilsom Pereira de. Colisão de direitos. A honra, a intimidade, a vida privada e a imagem versus a liberdade de expressão e informação. Porto Alegre: Sergio Antonio Fabris Editor, 1996. p. 27.

${ }^{39}$ DWORKIN, Ronald. Levando os direitos a sério. Tradução de Nelson Boeira. São Paulo: Martins Fontes, 2002. p. 43.
} 


$$
\text { peso. }^{40}
$$

A última das fases do processo de ponderação de que trata o professor Humberto Ávila e que mencionamos acima, é o momento em que se faz a reconstrução da ponderação (Rekonstruktion der Abwägung), "mediante a formulação de regras de relação, inclusive de primazia entre os elementos objeto de sopesamento, com a pretensão de validade para além do caso".

Ao sopesar princípios colidentes (de sinais trocados entre si), um intérprete pode entender como preponderante, tendo em vista as especificidades do caso concreto, um deles e outro intérprete decidir pelo contrário. No entanto, cabe à doutrina propor e entabular, minimamente, elementos que devam ser levados em consideração para a eficaz ponderação entre esses princípios constitucionais em conflito quando do exercício das liberdades comunicativas. E é exatamente isso que tentaremos a seguir.

\section{PROPOSTA DE CRITÉRIOS PARA A PONDERAÇÃO ENTRE OS PRINCÍPIOS EM COLISÃO AQUI EXAMINADOS}

A doutrina e a jurisprudência brasileiras têm reiterado um rol de situações a servir de temperamento ao caráter e sentido dos princípios aqui potencialmente colidentes, de modo a contribuir com a ponderação entre eles e o deslinde da antinomia real. Reconhecemos as cinco circunstâncias fático-jurídicas a seguir elencadas como as principais a serem levadas em conta como critérios de ponderação entre os princípios: 1) redução da esfera de proteção dos direitos da personalidade de pessoas ditas "pessoas púbicas"; 2) vedação do discurso de ódio - hate speech; 3) direito ao esquecimento; 4) animus jocandi e 5) redução da esfera de proteção dos direitos da personalidade do criminoso ou do acusado do cometimento de crime.

\subsection{Redução da esfera de proteção dos direitos da personalidade de pessoas ditas "pessoas públicas"}

É comum a menção a uma "redução na esfera de proteção da honra, imagem, vida privada e intimidade das pessoas públicas". E esta é uma generalização com a qual não se pode concordar, em absoluto, por razões (i) de imprecisão quanto aos sujeitos, (ii) de alcance em relação aos direitos atingidos, (iii) de intensidade em relação ao nível de redução a ser suportado e (iv) de motivação suficiente nos casos concretos para determinar esta drástica redução de uma proteção a direito essencial e imanente à personalidade.

(i) Quanto à imprecisão da formulação, perguntamos: quem são pessoas públicas? Uma celebridade-relâmpago, de fama efêmera, recém integrante de um reality show televisivo é pessoa pública? Todas as pessoas por quem se interessa o público, automaticamente, assumem tal condição? Quer nos parecer que só deveriam ser pessoas sujeitas a algum sacrifício de sua privacidade

40 ALEXY, Robert. Teoria dos direitos fundamentais. 2. ed. Tradução de Virgílio Afonso da Silva. São Paulo: Malheiros, 2014. p. 93-94. 
e imagem aquelas que: a) voluntariamente abriram mão de seu resguardo exibindo-se ao público para além da exposição natural do homem médio, em virtude de atividade artística ou atlética, ou qualquer outra a que favoreça a exposição midiática ou b) tenham o poder de influir na vida social, através da política ou da governança pública, tendo seu comportamento e biografia relação possível com o desempenho de atividades que repercutam nas vidas das pessoas comuns do povo. Como já tivemos ocasião de escrever alhures ${ }^{41}$

Formulando um conceito de pessoa pública, Alcides Leopoldo e Silva Junior em seu "A pessoa pública e o seu direito de imagem" asseverou que esta seria a que:

se dedica à vida pública ou que a ela está ligada, ou que exerça cargos políticos, ou cuja atuação dependa do sufrágio popular ou do reconhecimento das pessoas ou a elas é voltado, ainda que para entretenimento e lazer, mesmo que sem objetivo de lucro ou com caráter eminentemente social, como são por exemplo, os políticos, esportistas, artistas, modelos, socialites e outras pessoas notórias. ${ }^{42}$

Em que pese a visão acima manifestada, entendemos como pessoa submetida à mitigação da proteção de seus direitos de imagem e de privacidade aquelas que se expõem ao escrutínio público. As outras pessoas, que chamam a atenção do público porque têm algum talento especial, mas que se mantém longe da ribalta e procuram preservar seu resguardo em relação aos olhares alheios, e que, por outro lado, não exercem função pública (de Estado) estas merecem a mesma exata proteção de suas privacidade e imagem que tem qualquer cidadão. Por mais que haja interesse do público (e não "interesse público") sobre suas vidas, estas deverão ser desveladas à curiosidade do povo apenas e tão somente na medida exata do quanto pretenda o titular do direito à privacidade.

Adverte Ivana Có Galdino Crivelli ${ }^{43}$ que apenas pode ser mitigada a proteção da privacidade e da intimidade ante um relevante interesse público, sendo que "a intimidade e a privacidade do ser humano devem ser protegidas contra a devassa voltada a agraciar o interesse do público por bisbilhotices".

A solução encontrada pelo Código Civil português foi elencar como situações ensejadoras da limitação aos direitos da personalidade, previstos no art. $70^{\circ}$ daquele diploma: a) notoriedade da pessoa; b) cargo público exercido; c) necessidades de justiça ou de polícia; d) fins científicos, didáticos ou culturais e e) repercussão relacionada com fatos, acontecimentos, cerimoniais de interesse público ou ocorridos em público.

(ii) No que respeita ao alcance dos direitos atingidos: note-se que ao tratar acima dos sujeitos a ser considerados "pessoas públicas", mencionamos apenas a privacidade e a imagem e o fizemos propositalmente, exatamente por acreditarmos que a honra e a intimidade das pessoas sob nenhuma hipótese estarão vulnerabilizadas, mesmo quando tais pessoas se encaixem à perfeição no gabarito

${ }^{41}$ BENTIVEGNA, Carlos Frederico Barbosa. Liberdade de Expressão, honra, imagem e privacidade. Os limites entre o lícito e o ilícito. São Paulo: Manole, 2019, p. 221

42 SILVA JUNIOR, Alcides Leopoldo e. A pessoa pública e o seu direito de imagem. São Paulo: Juarez de Oliveira, 2002, p. 88

${ }^{43}$ CRIVELLI, Ivana Có Galdino. Intimidade e privacidade na era da informação. In: Direitos da personalidade. A contribuição de Silmara J. A. Chinellato, CORREIA, Atalá; CAPUCHO, Fábio Jun (coords). Barueri: Manole, 2019. p. 257. 
daquelas por cujas vidas haja legítimo interesse público. Um (i) artista "exibicionista" que se mostra a si e à sua casa - em edições sucessivas de revistas de fotos de famosos ou (ii) um político ocupante de importante cargo executivo deve suportar em maior medida incursões às suas privacidades e o uso de suas imagens. No entanto, nem mesmo estes indivíduos estarão obrigados a tolerar ataques à sua honorabilidade ou invasão à sua intimidade.

Nada justifica, entre seres civilizados, o achincalhe à honra alheia, mesmo em nome do embate político, da crítica a atividade artística ou intelectual etc. O exame do caso concreto dirá, em todos os casos, incluídas aí as pessoas notórias (expressão que preferimos a "públicas") e as comuns do povo ${ }^{44}$, se uma crítica se deu nos limites da liberdade de manifestação de um juízo sobre outrem mesmo que desfavorável ou até azeda - ou se desbordou para um injustificável ataque à honra. Entendemos que aí não há subjetividades, portanto, não haveria razões para o discrimen entre pessoas notórias ou não.

Com relação à intimidade dá-se o mesmo. A ninguém é dado invadir a esfera íntima (o mais estreito dos círculos concêntricos da privacidade) de outrem, muito menos amparado apenas em razões como a de ser fulano uma "pessoa pública". Chegamos a ler, não sem grande surpresa, em obra recente, a afirmação de que "um político não tem o direito de esconder do público, seus potenciais eleitores, sua opção sexual". Com todo o respeito, trata-se de afirmação teratológica, pois a vida sexual de quem administra o patrimônio público não terá qualquer influência sobre esta atividade específica. Houve na jurisprudência inglesa o caso de um político, ocupante de cargo importante, que tinha uma amante e esta amante mantinha também relações amorosas concomitantes com um diplomata soviético a quem poderia cometer inconfidências estrategicamente delicadas para a segurança nacional. Julgou-se tal informação de interesse público, e com razão nesta situação específica! Vejase que o sacrifício da informação íntima não se deu por razão outra se não um real e comprovado interesse público (raríssimo nessas hipóteses, a propósito). Não à toa o interesse é público e a intimidade é privada. As palavras querem dizer o que significam.

Já disseram sobre o tema J.J. Gomes Canotilho e Vital Moreira que:

o direito à imagem $\left(n^{\circ} 1\right)$ tem um conteúdo assaz rigoroso, abrangendo, primeiro, o direito de definir a sua própria auto-exposição, ou seja, o direito de cada um de não ser fotografado, nem de ver o seu retrato exposto em público sem seu consentimento (cfr. Ccivil, art. $\left.30^{\circ}\right)$; e, depois, o direito de não o ver apresentado em forma gráfica ou montagem ofensiva e malevolamente distorcida ou infiel ("falsificação da personalidade"). Torna-se evidente que não pode gozar do direito à imagem (pelo menos no primeiro sentido) quem ocupe cargo ou desempenhe função em que a publicidade (isto é, o conhecimento e a relação com o público) seja elemento essencial, havendo aí uma espécie de 'acordo' ou 'consentimento' implícito (aí estando um fator de ponderação em caso de colisão deste direito fundamental com outro direito: cfr. Nota $\mathrm{VI}$ ao art. $18^{\circ}$ ). Esta dimensão de publicidade legitimadora de algumas restrições ao direito à imagem não deve, porém, transferir-se para a esfera da intimidade (cfr. Nota X)" (grifos nossos). ${ }^{45}$

44 Bruno Franceschelli se utiliza das expressões "una distinzione tra persona celebre e comune mortale". FRANCESCHELLI, Bruno. Diritto alla riservatezza. Napoli: Casa Editrice Dott. Eugenio Jovene, 1960. p. 70.

45 CANOTILHO, J. J. Gomes; MOREIRA, Vital. Constituição da república portuguesa anotada. vol 1. Edição conjunta de Coimbra Editora (Coimbra) e Revista dos Tribunais (São Paulo), 2007. p. 467. 
Colhe-se da lição de outro jurista português de escol, Menezes Cordeiro ${ }^{46}$, a assertiva no sentido de que a notoriedade de políticos e celebridades implica em restrição da privacidade, mas "nunca ao ponto de atingir as esferas secreta e íntima".

(iii) Agora, quanto à intensidade em relação ao nível de redução a ser suportado: felizmente quase não se encontra mais quem afirme na doutrina que as pessoas públicas têm suprimida a proteção à honra, imagem, vida privada e intimidade em face do interesse público e da liberdade de informação. Já é corrente a ideia de que há apenas um temperamento nessa proteção, sendo de ser apenas levada em conta a circunstância, da notoriedade e suas consequências, numa operação de ponderação entre os valores da liberdade de expressão e da proteção aos direitos da personalidade.

De forma alguma ter-se-á a supressão da privacidade ou da proteção à imagem das pessoas notórias, o que se verá é uma mitigação do rigor dessa interdição do acesso aos olhos curiosos da sociedade à imagem e aos aspectos privados da vida de pessoas naquelas circunstâncias. Isso se essa circunstância pesar o suficiente na operação de ponderação (balancing) entre os valores conflitantes. $\mathrm{O}$ aqui já múltiplas vezes citado Paulo José da Costa Júnior ${ }^{47}$, ao mencionar um parcial sacrifício do direito à intimidade, quando o interesse do particular for suplantado por questões de ordem pública, mencionou que estava tratando de redução, ou "diminuição da intimidade e não de sua eliminação total. Porque o interesse público haverá que se deter diante daquela esfera mais íntima da vida privada que, como tal, é inviolável. A intromissão, ali, do interesse público não encontraria justificação, degradando-se este a mera curiosidade".

A primeira demanda a julgar e reconhecer o direito à intimidade de que se tem notícia já reconheceu a mitigação deste direito ao se tratar de "pessoas públicas". Conforme notícia trazida por Edilsom de Farias ${ }^{48}$, fruto de sua pesquisa profunda, trata-se de sentença de 1892, proferida por um juiz de Nova York no caso Schuyler v. Curtis, onde se utilizou a então recentíssima doutrina de Warren e Brandeis (The Right to Privacy), já estatuindo, no entanto, uma diferença no grau de proteção à intimidade entre as "pessoas públicas" e aquelas sobre as quais não há o interesse social justificado. Assim se pronunciou o juiz neste precedente histórico:

The moment one voluntarily places himself before the public, either in accepting public office, or in becoming a candidate for office, or as an artist or literary man, he surrenders his right to privacy, and obviously can not complain of any fair or reasonable description or portraiture of himself.

(iv) No que respeita à motivação suficiente nos casos concretos para determinar esta drástica redução de uma proteção a direito essencial e imanente à personalidade: temos que o exame do caso concreto será determinante para separar o real interesse público da curiosidade popular. Esta última, de natureza às vezes mórbida, mas sempre fútil, nunca será razão suficiente para a mitigação de uma proteção dessa importância. Lembre-se nesse ponto das explicações de Adriano De Cupis, por

${ }^{46}$ CORDEIRO, António Menezes. Tratado de direito civil português, vol. I, parte geral, Tomo III. Coimbra: Almedina, 2004. p. 211.

${ }^{47}$ COSTA JÚNIOR, Paulo José da. O direito de estar só - Tutela penal da intimidade. 2. ed., São Paulo: RT, 1995. p. 45.

${ }^{48}$ FARIAS, Edilsom Pereira de. Colisão de direitos. A honra, a intimidade, a vida privada e a imagem versus a liberdade de expressão e informação. Porto Alegre: Sergio Antonio Fabris Editor, 1996. p. 115. 
exemplo, sobre a essencialidade dos direitos da personalidade para refletir se a mera vontade popular de penetrar a intimidade alheia teria o condão de afastar tal inviolabilidade.

A motivação para que se permita, num processo de ponderação entre a tutela da privacidade alheia e a liberdade de expressão em sentido lato, afastar a prerrogativa que têm as pessoas de manterse no absoluto controle sobre os aspectos de sua vida que pretendam sejam descortinados ao público em geral deve, obrigatoriamente, demonstrar um interesse realmente social, vale dizer, público naquela informação ou dado, sob pena de se estar alimentando apenas a mórbida curiosidade popular sobre a vida alheia, algo absolutamente indigno de proteção e garantia legais.

Repugna às consciências verdadeiramente democráticas a ideia de que, ao invés do exame imparcial e desapaixonado do caso concreto, através da ponderação entre os princípios, se aniquile o espaço pessoal de exercício pleno da individualidade, com seu reflexo mais óbvio que é a intimidade, em nome de um erro exegético em que se constitui uma alegada "preferência prima facie" de um dos valores sopesados entre si. Como se pode admitir que a sexualidade - manifestação psicofisiológica do afeto do indivíduo no mais recôndito de sua intimidade - de um político possa ser algo impossível de ser mantido longe dos olhos do público em nome da democracia? Tal entendimento nos parece carecer absolutamente de qualquer sentido lógico! A ideia de restringir a cláusula democrática à simples ideia de "tudo noticiar" ou de "cada um dizer absolutamente tudo o que pensa sobre todos os demais a todos os outros" é de um reducionismo espantoso. Numa sociedade verdadeiramente democrática, as personalidades devem encontrar terreno fértil para o seu pleno desenvolvimento, com a garantia legal daqueles direitos que Ihes são essenciais que são "os direitos supremos do homem, aqueles que garantem o gozo de seus bens pessoais... garantem o gozo de nós mesmos, asseguram a cada um a senhoria de sua pessoa, a atuação das próprias forças físicas e espirituais" ${ }^{49}$. Entre eles, indubitavelmente, a intimidade, a vida privada, a imagem e a honra.

Vimemos uma era, segundo Daniel Pizarro, de incremento da curiosidade, por vezes mórbida, do público por questões da vida privada das pessoas, o que se transformou em algo a ser explorado pelos meios de comunicação - "com inquietante frequência", diz Pizarro - com o intuito de auferir lucro. "Dentro de um marco semelhante, o conflito entre o direito à informação e os direitos personalíssimos dos protagonistas da notícia é tão frequente quanto inevitável. Tanto a prevenção do dano, quanto a sua reparação passam a ocupar um lugar relevante no mundo jurídico contemporâneo, impondo uma profunda revisão dos numerosos esquemas clássicos, que perderam idoneidade, em boa medida, para dar soluções justas" 50 .

Dedicou-se o penalista português Manuel da Costa Andrade, no seu importante e aqui já citado "Liberdade de Imprensa e Inviolabilidade Pessoal" ${ }^{51}$ à caracterização dos casos em que se

${ }^{49}$ FERRARA, Francesco, Tratatto di diritto civile italiano. Roma:Atheneum, 1921. p. 388.

${ }^{50}$ PIZZARRO, Ramon Daniel. Responsabilidad civil de los medios masivos de comunicación. Daños por noticias inexactas o agraviantes. Buenos Aires: Editorial Hammurabi, 1991, p. 64. Tradução livre de: "Dentro de un marco semejante, el conflito entre el derecho a la información y los derechos personalísimos de los protagonistas de la noticia es tan frecuente como inevitable. Tanto la prevención del daño cuanto su reparación pasan a ocupar un lugar relevante en el mundo jurídico contemporâneo, imponiendo una profunda revisión de numerosos esquemas clásicos, que han perdido idoneidad, en buena medida, para dar soluciones justas."

${ }^{51}$ ANDRADE, Manuel da Costa. Liberdade de imprensa e inviolabilidade pessoal. Uma perspectica jurídicocriminal. Coimbra: Coimbra Editora, 1996. pp. 260-261. 
justifica o sacrifício parcial da proteção aos direitos da personalidade, em especial da intimidade, para prestigiar o interesse público. Ali cita o eminente jurista o célebre Caso Profumo, que mencionamos há pouco.

Lê-se das lições de Costa Andrade, que se devem verificar os fatos in concreto, sendo apenas relevante, por exemplo, (i) a sexualidade do agente público, no caso da pedofilia, relacionada de perto com o cuidado de crianças, ou, ainda, (ii) a infidelidade conjugal do ministro, por relacionar-se com questões de Estado e assim por diante. É falsa qualquer resposta apriorística à indagação sobre se tem uma pessoa notória o direito a preservar informação quanto à sua intimidade, sendo que a tendência inercial milita, sem dúvida, em favor do sim.

E o que dizer a respeito das divulgações sobre o patrimônio dos "100 homens mais ricos" da Revista $x$ ou y? Das notícias pormenorizadas acerca de aquisições de bens de alto luxo por parte da elite financeira de um determinado grupo social?

Aqui não paira qualquer dúvida plausível acerca da ilicitude de tal invasão à esfera privada. Invasão totalmente nefasta que pode gerar, inclusive, graves riscos à incolumidade física do alvo da notícia e de seus familiares em sociedades conflagradas como a brasileira, onde grassam os roubos e extorsões mediante sequestro. A ninguém é dado reconhecer como "de interesse público" a notícia quanto ao patrimônio alheio, a não ser em casos que a própria a lei assim o determina (candidatos, devem apresentar declaração patrimonial ao Tribunal Eleitoral por ocasião de sua inscrição; funcionários públicos também o fazem no ato da posse no cargo ou função, como forma de sindicar eventual acréscimo patrimonial incompatível no futuro, etc).

Há que se excepcionar os casos em que esta proteção do sigilo quanto à vida privada, em seus aspectos patrimoniais, é alvo de renúncia expressa ou tácita por parte do seu titular. Dá-se a renúncia expressa quando o titular é consultado sobre reportagens desse jaez ou fornece os dados de que esta se utilizará. Tácita, segundo o nosso sentir, quando se trata de "pessoa notória e de notório exibicionismo" que é useira e vezeira em figurar nas revistas de fotografias de "ricos e famosos" a ostentar seu patrimônio sem qualquer indício que queira dele fazer segredo.

\subsection{A vedação do discurso de ódio - "hate speech"}

Até mesmo na "Meca da Liberdade de Expressão", que são os Estados Unidos da América, onde a garantia da liberdade de expressão tem contornos alargados numa proporção não encontrada em qualquer outro sistema jurídico, desenvolveu-se a teoria da vedação do "dicurso de ódio" (hate speech), como um limitador dessa liberdade pública, de forma a evitar a propagação de ideias segregacionistas e que gerem convulsões sociais e animosidade no seio da sociedade.

Alex Potiguar nos fornece, em seu "Liberdade de Expressão e o Discurso de Ódio", uma definição para o discurso de ódio:

o hate speech é definido por Michael Rosenfeld como o discurso para promover o ódio baseado na raça, religião, etnia ou nacionalidade, e podemos acrescentar, ainda, gênero ou opção sexual. Ele é o discurso que exprime uma ideia de ódio, desprezo ou intolerância contra determinados grupos, menosprezando-os, desqualificando-os ou 
inferiorizando-os pelo simples fato de pertencerem àquele determinado grupo, motivado por preconceitos ligados à etnia, religião, gênero, deficiência, orientação sexual, nacionalidade, naturalidade, dentre outros. ${ }^{52}$

Necessário, no entanto, atentar para o quanto não é discurso de ódio, mas sim posicionamento contrário a ideias que beneficiem grupos minoritários, pelas razões mais diversas. Assim, a discordância ou argumentação contrária (i) às políticas de cotas ou discriminações afirmativas; (ii) à possibilidade de casamento homoatefivo ou (iii) o simples proselitismo de uma determinada crença como único caminho de "salvação das almas" etc. Não praticaria hate speech o pastor de uma das seitas neopentecostais que afirmasse, por exemplo, que "quem não vive segundo os cânones da bíblia está sujeito à danação eterna", ou ainda que "afirme ser pecado viver maritalmente com alguém do mesmo sexo". Tais afirmações, posto que assertivas contra alguns comportamentos, não carregam em si a ilicitude do discurso de ódio - carregando apenas a insensatez e o mau gosto de tentar impor ao público, em geral, uma regra moral de adesão voluntária e restrita àquele grupo a que pertence o emissor da mensagem.

O nascedouro da teoria do hate speech deu-se no âmbito da questão racial, mas a ela não se resume esta vedação a limitar a liberdade de expressão. Qualquer pregação de ódio ou defesa da inferioridade de determinado grupo, por quaisquer motivos é de ser razão para o afastamento da proteção à livre manifestação do pensamento.

$\mathrm{Na}$ jurisprudência norte-americana também viu-se surgir a doutrina do repúdio às fighting words, ou palavras belicosas, isto é, palavras que se constituem em "estopins de ação, em vez de pautas de persuasão", para, aqui, usar as felizes expressões de Paulo Branco. Para ele "a diferença entre uma discussão robusta e uma diatribe repelida pela Constituição está em que, no primeiro caso, há chance e oportunidade de se corrigirem os erros do discurso, expondo a sua falsidade e as suas falácias, evitando o mal por meio de um processo educativo. Nesses casos, o remédio seria mais liberdade de expressão, mais discurso. No caso desviado da Constituição, essa perspectiva não existe" 53 . De maneira alguma, a hostilidade do princípio da liberdade de expressão às fighting words significa que estejam excluídas da proteção constitucional as palavras mais duras ou desagradáveis. Não apenas o discurso melífluo e aprazível há de ser protegido! No entanto, aquele que se presta apenas à fustigação, à instigação da ação combativa alheia, este não é amparado pela liberdade de expressão em sentido lato garantida pela Constituição.

A teoria dos limites imanentes, desenvolvida por J. J. Gomes Canotilho ${ }^{54}$ defende exatamente a existência de "limites imanentes da ordem social, limites eticamente imanentes", que são restrições internas e não externas do direito subjetivo. Assim, o discurso de ódio nem faria surgir um conflito entre os princípios constitucionais da (i) liberdade de expressão e (ii) da dignidade de pessoa humana, porquanto, de forma imanente, já encontraria o obstáculo de ver-se subtraído do alcance do conceito

52 POTIGUAR, Alex. Liberdade de expressão e o discurso de ódio - A luta pelo reconhecimento da igualdade como direito à diferença. Brasília: Ed. Consulex, 2012. p. 16.

${ }^{53}$ MENDES, Gilmar Ferreira; BRANCO, Paulo Gustavo Gonet. Curso de direito constitucional. 11. ed. São Paulo: Saraiva, 2016. p. 273.

54 CANOTILHO, J. J. Gomes. Direito constitucional e teoria da constituição. 7. ed. Coimbra: Almedina, 2003. p. 1.280 . 
de liberdade de expressão.

A propósito dos aspectos sociológicos a envolver a coibição do discurso de ódio, colhe-se a lição de Alex Potiguar, para quem:

o combate ao hate speech pode variar de uma tendência mas liberal, que visa a estender ao máximo a liberdade de expressão, como é o caso da jusrisprudência norteamericana, que nem sequer enxerga, na maioria dos casos discutidos, o direito à igualdade, até a rigorosa tendência alemã, que pune a mera opinião nos casos de antissemitismo e de negação do Holocausto. Em outras palavras, do laissez-faire americano à vigilância alemã. ${ }^{55}$

Tal diferença dá-se, seguramente, devido aos antecedentes históricos e político-sociológicos de cada qual dos países acima mencionados. Enquanto os Estados Unidos da América lutavam contra a opressão do império colonizador quando de sua fundação e previram, na first amendment à sua Constituição, um direito quase absoluto à liberdade de contestação política e manifestação de qualquer ideia; a República Federal Alemã, por seu turno, convive com os fantasmas do nacional socialismo que, começou promovendo singelo discurso de ódio para, em seguida, passar para um plano de dominação continental e extermínio de "raças inferiores", circunstância histórica que constrange até hoje o povo alemão.

\subsection{Direito ao esquecimento ${ }^{56}$}

De fundamental importância é levar-se em conta, igualmente, o chamado "direito ao esquecimento". Esta seria a prerrogativa que teria aquele que já foi legitimamente alvo de notícia a ser esquecido e "deixado em paz" pela perda de atualidade daquele fato que, embora já tenha sido do interesse público, hoje não tenha mais tal característica.

Em artigo escrito por Antonio Carlos Morato e Maria Cristina De Cicco, intitulado "Direito ao Esquecimento: Luzes e Sombras" ${ }^{57}$, vê-se uma interessante referência interdisciplinar, vinda da neurociência, ao citar o médico Iván Izquierdo - que foi responsável pelo Centro de Memória do Departamento de Bioquímica da Universidade Federal do Rio Grande do Sul - para quem o esquecimento é conditio sine qua non para a convivência harmônica entre animais de qualquer espécie, incluindo os seres humanos. Prossegue o neurocientista exemplificando, por absurdo, o caos de um mundo sem o esquecimento: "cada reunião de condomínio, cada jogo de futebol, cada eleição para

${ }^{55}$ POTIGUAR, Alex. Liberdade de expressão e o discurso de ódio - A luta pelo reconhecimento da igualdade como direito à diferença. Brasília: Ed. Consulex, 2012. pp. 17/18.

${ }^{56}$ Recente decisão do STF, com repercussão geral, em RE no 1010606, rel. Min. Dias Toffoli, julgando um caso concreto em que não se punha em discussão a existência ou não do Direito ao Esquecimento, mas sim sua aplicabilidade em caso que era de reparação civil por danos morais, acabou por declará-lo incompativel com a ordem constitucional. No entanto, isso não afeta o reconhecimento da doutrina nacional e internacional e a existência de jurisprudência consolidada em países como a Alemanha e os Estados Unidos da América. Entende o autor que a decisão não enfrentou de forma correta e com a profundidade necessária o tema e que o instituto deve voltar a ser discutido em breve naquela Suprema Corte - mas o aprofundamento no exame daquele Acórdão é assunto que demandaria (e merecerá) um outro artigo que disso trate com exclusividade.

${ }^{57}$ MORATO, Antonio Carlos; DE CICCO, Maria Cristina. Direito ao esquecimento: luzes e sombras. In Estudos em homenagem a Ivette Senise Ferreira. SILVEIRA, Renato de Mello Jorge; GOMES, Mariângela Gama de Magalhães (orgs), São Paulo: LiberArs, 2015. p. 80. 
vereador, cada discussão de um casal, acabariam num desastre".

Na sequência, aduz Antonio Carlos Morato, verbis:

\begin{abstract}
a concepção de esquecimento, em tal contexto, manifesta-se como um imperativo biológico da espécie humana e, desse modo, na mesma medida em que olvidamos momentos felizes de nossa existência que gostaríamos de manter tanto em nossa memória como na de toda a coletividade por meio da reafirmação de pequenas conquistas pessoais ou profissionais, a contrapartida é a de que o próprio indivíduo, seus amigos, familiares e a coletividades esqueçam-se desde os desentendimentos do cotidiano até situações mais graves que permitam o convívio social e viabilizem a cicratização de longínquas feridas. Cumpre observar que a cicatrização é ameaçada por meio de muitas situações que não refletem necessariamente o interesse da sociedade por meio de uma pesquisa efetiva ou de um genuíno interesse jornalístico calcado em aspectos históricos ou em situações que possam servir ao menos como uma referência pedagógica - mesmo que atreladas a situações particulares - para as gerações atuais. ${ }^{58}$
\end{abstract}

Surge a doutrina do "direito ao esquecimento" no exame da situação dos condenados em ações penais que, uma vez cumpridas suas penas, têm o direito à ressocialização - que é o fim último de todo o sistema de apenamento. Esta ficaria prejudicada na hipótese de voltar à tona a todo momento a notícia "requentada" dos fatos que levaram à condenação. Mas não é só ao Direito Penal que interessa a doutrina do direito ao esquecimento, pois ela serve, exatamente, à proteção da intimidade, da vida privada, da imagem e da honra das pessoas envolvidas em fatos desabonadores que, pelo decurso do tempo, já eram de ter sido relegados ao esquecimento do público.

Maria Cristina De Cicco, no artigo citado acima, conceitua o direito ao esquecimento (diritto all'oblio) da seguinte forma: "de matriz francesa, tal é o direito de uma pessoa a não ver publicadas notícias, já legitimamente veiculadas, concernentes a vicissitudes que lhe dizem respeito, quando entre o fato e a republicação tenha transcorrido um longo tempo". 59

De Cicco assevera que, ao se partir do pressuposto de que o direito ao esquecimento configura "um direito fundamental da pessoa", tanto a doutrina quanto a jurisprudência italianas vêm se dedicando a identificar critérios que sejam úteis à árdua tarefa de proceder à ponderação entre este direito e a eventual "existência e permanência de um interesse público à veiculação da notícia, conjugado com a atualidade" 60 .

$E$, de fato, colhe-se da jurisprudência italiana muitas decisões da mais alta Corte Constitucional, a Corte di Cassazione, no sentido de prestigiar o instituto do direito ao esquecimento, já há quase quarenta anos, como, por exemplo:

Corte di Cassazione, 18 Ottobre del 1984, n. 5259

Dado que por direito ao esquecimento se entende o legítimo interesse de qualquer pessoa de não permanecer indefinidamente exposta aos danos ulteriores que acarreta à sua honra e à sua reputação a reiterada republicação de uma notícia, no passado legitimamente divulgada, não constitui legítimo exercício do direito de informação a publicação de fatos já tornados notórios seis anos antes, salvo se

58 MORATO, Antonio Carlos; DE CICCO, Maria Cristina. Direito ao esquecimento: luzes e sombras. In Estudos em homenagem a Ivette Senise Ferreira. SILVEIRA, Renato de Mello Jorge; GOMES, Mariângela Gama de Magalhães (orgs), São Paulo: LiberArs, 2015. p. 92.

59 Idem. p. 92.

60 Idem. p. 93. 
eventos supervenientes tornem novamente atuais aqueles fatos, fazendo surgir um novo interesse público pela divulgação da informação. ${ }^{61}$

Ao tratar do assunto, François Ost, em seu "O Tempo do Direito" afirma que o próprio instituto da prescrição é uma espécie de "direito a um esquecimento programado" e acrescenta, enfatizando a aplicação do direito ao esquecimento na defesa dos direitos da personalidade pela jurisprudência francesa:

\begin{abstract}
Em outras hipóteses, ainda, o direito ao esquecimento, consagrado pela jurisprudência, surge mais claramente como uma das múltiplas facetas do direito ao respeito à vida privada. Uma vez que, personagem pública ou não, fomos lançados diante da cena e colocados sob os projetores da atualidade - muitas vezes, é preciso dizer, uma atualidade penal -, temos o direito, depois de determinado tempo, de sermos deixados em paz e a recair no esquecimento e no anonimato, do qual jamais queríamos ter saído. Em uma decisão de 20 de abril de 1983, Mme. Filipachi Cogedipresse, o Tribunal de última instância de Paris consagrou este direito em termos muito claros: “(...) qualquer pessoa que se tenha envolvido em acontecimentos públicos pode, com o passar do tempo, reivindicar o direito ao esquecimento; a lembrança destes acontecimentos e do papel que ela possa ter desempenhado é ilegítima se não for fundada nas necessidades da história ou se for de natureza a ferir sua sensibilidade; visto que o direito ao esquecimento, que se impõe a todos, inclusive aos jornalistas, deve igualmente beneficiar a todos, inclusive aos condenados que pagaram sua dívida para com a sociedade e tentam reinserir-se nela". 62
\end{abstract}

\title{
5.4. Animus jocandi - Si quis per jocum percuriat, injuriarum non tenetur
}

Por vezes se expressam as liberdades comunicativas de forma a que a intenção do emissor da mensagem (quer seja ela falada, visual, escrita etc.) seja comunicar e a um só tempo provocar no destinatário da mensagem o riso. Trata-se do animus jocandi, ou seja, da manifestação do pensamento (ou da criação do espírito) através do humor, da sátira e da caricatura.

Muito mais do que apenas "um estímulo provocador de reflexos motores, responsáveis por contrair coordenadamente mais de 15 músculos faciais"63, o riso, na verdade, é um fenômeno social e comunicacional muito mais complexo que, em virtude de tal complexidade "atingiu a interdisciplinaridade, podendo ser estudado pela Semiótica, Literatura, História, Sociologia, Psicologia, dentre outras ciências". E, por óbvio, cabe ao Direito um importante papel nesse estudo que é o de fixar os lindes consequenciais do exercício do humor, da busca pelo riso.

As perguntas que aqui se impõem são: Teria o exercício da prática satírica, humorística ou caricatural um limite mais elástico de contenção em face do respeito aos direitos de personalidade alheios? Ou seria este limite idêntico àquele imposto a qualquer outro que exprima seu pensamento de forma diferente ou por meio diferente (crítica jornalística, ensaio literário, noticiário televisivo, etc), no

61 Tradução livre de: "Posto che per diritto all'oblio si intende il legittimo interesse di ogni persona a non restare indeterminatamente esposta ai danni ulteriori che arreca al suo onore ed alla sua reputazione la reiterata pubblicazione di una notizia, in passato legittimamente divulgata, non costituisce legittimo esercizio del diritto di cronaca la pubblicazione di fatti già resi noti sei anni prima, salvo che eventi sopravvenuti rendano novamente attuali quei fatti, facendo sorgere un nuovo interesse pubblico alla divulgazione della informazione".

62 OST, François. O tempo do direito. Trad. Élcio Fernandes. Bauru: EDUSC, 2005. p. 160-161.

63 RIGAMONTE, Paulo Arthur Germano; SILVEIRA, Daniel Barile da. Liberdade de expressão e humor. Curitiba: Juruá, 2018. p. 56. 
que tange ao respeito à personalidade alheia?

Sempre teve o riso, no correr do tempo, seus adeptos e seus detratores, desde correntes filosóficas da Grécia antiga que dele faziam apologia até ordens religiosas monásticas, no medievo, que o aboliram de seu convívio por entendê-lo demoníaco. Lembramo-nos do personagem de Umberto Eco no seu já clássico O Nome da Rosa, um monge beneditino extremamente cioso do cumprimento das Regras da Ordem, que tramava mortes por repugnar o humor e o riso, dizia que as contrações da face ocasionadas pelo riso afastavam o homem da imagem e semelhança divina e o aproximavam dos macacos.

Interessante o apanhado histórico feito por Daniel Barile da Silveira - professor que cursou Pós-Doutorado na gloriosa Universidade de Coimbra - em sua obra "Liberdade de Expressão e Humor", que já tivemos a oportunidade de citar em nosso "Liberdade de Expressão, Honra, Imagem e Privacidade" 64 , onde se lê:

\begin{abstract}
Mas a comédia em si foi explorada pelo teatro grego, em 501 a.C., quando teve início a era das tragédias e, poucos anos mais tarde, a das comédias. A tragédia era o espetáculo principal, sendo que a comédia era uma arte acessória, cujo objetivo era apenas relaxar os espectadores durante os intervalos das peças teatrais. Tinha-se como cômico o homem inferiorizado, rebaixado moral e socialmente, numa clara tentativa de explorar o ridículo, o grotesco do ser humano. Anos mais tarde, a comédia passa a assumir diversas facetas, ora tida como meio de crítica aos personagens públicos, ora como entretenimento e, em certos casos, até mesmo como significativo de inferioridade humana.

Nesse aspecto, Aristófanes (445 a 386 a.C.) foi o precursor da independência entre a comédia e os teatros trágicos, pois introduziu o cômico como forma de criticar as figuras públicas e os deuses da mitologia. Já Menandro (342 a 292 a.C.) tratou o riso como distração e divertimento, como uma forma de desapego dos problemas do diaa-dia. Assim, o homem era metaforicamente tratado como a corda de um arco, a qual se estica diante das necessidades, mas depois de ser usada, precisa ser afrouxada, pois se for mantida sempre tensa, ela arrebenta e torna-se inutilizável. Por outro lado, há ainda quem viu o riso com outros olhos. Platão atribuiu um conceito negativo ao risível, sendo este o fruto de homens medíocres e inferiores, porque apenas a filosofia era digna de apreensão da verdade, em oposição à ilusão característica das paixões. ${ }^{65}$
\end{abstract}

O riso se dá em presença do exagero. A caricatura é, por exemplo, a expressão do exagero das qualidades detectáveis nalgum objeto ou em determinada pessoa. Como é ínsito ao humor a ideia de exagero, este último, por si só, "não pode ser causa de dano à personalidade como o é em outros campos"66 quando estivermos diante do autêntico animus jocandi.

Refiro-me a um autêntico intuito de brincar, porque, por vezes, a roupagem do humor apenas é utilizada para mascarar intenções outras de ataque à honorabilidade alheia: animus difamandi vel iniuriandi. E, nesses casos, outra não é a solução se não impedir que se utilize da roupagem do humor como salvo conduto para a prática ilícita em vulneração da personalidade alheia.

Nesse sentido, necessário colher a lição, sempre lúcida, de Manuel da Costa Andrade, para

${ }^{64}$ BENTIVEGNA, Carlos Frederico Barbosa. Liberdade de expressão, honra, imagem e privacidade. Os limites entre o lícito e o ilícito. São Paulo: Manole, 2019. p. 276.

65 Idem. pp. 56-57.

${ }^{66}$ GODOY, Claudio Luiz Bueno de. A liberdade de imprensa e os direitos da Personalidade. 3. ed. São Paulo: Atlas, 2015. pp. 96-97. 
quem:

\begin{abstract}
a essência destas formas autónomas de criação artística reside precisamente na exploração, sem limites, do grotesco, do ridículo, em suma, daquilo que, a qualquer luz, sobressai em determinada expressão da realidade. (...) Seja ou não assim, uma coisa sobra como líquida: a caricatura e a sátira alimentam-se invariavelmente do exagero e da hipérbole, da acentuação desproporcionada e deformada de aspectos do real, de marcas da imagem ou de traços do caráter. Como já Kant enfatizava, a essência da caricatura reside 'no exagero do característico, isto é, dos desvios individuais em relação à ideia normal, à imagem média' ${ }^{67}$
\end{abstract}

Mais adiante e amparando-se em julgado do Tribunal Constitucional de Karlsruhe, o autor esclarece que este exagero e distanciamento da precisão fática são características inseparáveis desta roupagem da manifestação do pensamento que é o humor. Assim, para Costa Andrade, a análise jurídica do caso concreto imprescinde de um questionamento separado da mensagem e da roupagem humorística, com vistas a saber se houve ou não um desrespeito a aspecto da personalidade do alvo da mensagem satírica: lembrando-se sempre de que "os critérios para a apreciação da roupagem serão diferentes e, por via de regra, menos exigentes que os da valoração do Aussagekern. Isto porque a distanciação é conatural àquela".

E prossegue o jurista português, comentando a jurisprudência constitucional alemã sobre o tema:

À roupagem cabe, assim, uma função prevalentemente apelativa: emprestar visibilidade e força à mensagem a transmitir. Acresce que é sobretudo na roupagem que se actualiza a liberdade de criação artística da sátira e da caricatura. O que confirma a expectativa já antecipada e segundo a qual a roupagem não colidirá normalmente com a dignidade pessoal. A acontecer, a colisão há-de, em princípio, levar-se à conta de custo social a suportar em nome da liberdade de criação artística. (...)

b) Só não será assim nos casos extremados em que a roupagem configura já ela própria um atentado irredutível e intolerável à dignidade humana. Então, para além de ser irrecusável a tipicidade, poderá igualmente ter de concluir-se pela insubsistência de justificação bastante para derimir a ilicitude indiciada.

Com relação a esta "roupagem" de que se reveste a mensagem humorística, vale aqui lembrar a origem etimológica de CARICATURA: vem da palavra homógrafa da língua italiana, priveniente do verbo caricare, ou seja, "carregar", "exagerar", "forçar nas tintas", com o intuito de se atingir o ridículo, o risível.

\title{
5.5. Redução da esfera de proteção dos direitos da personalidade do criminoso ou do acusado do cometimento de crime
}

No que tange às pessoas condenadas em processo criminal ou acusadas pelo cometimento de crime, sem dúvida lhes será aplicada uma mitigação (ou redução) sobre a proteção seus direitos da personalidade aqui em estudo: honra, imagem, vida privada e intimidade. Isso, por óbvio, não implica,

${ }^{67}$ ANDRADE, Manuel da Costa. Liberdade de imprensa e inviolabilidade pessoal. Uma perspectiva jurídicocriminal. Coimbra: Coimbra Editora, 1996. pp. 242-245. 
de forma alguma, a supressão de tais direitos, dado que essenciais à condição humana, mas apenas uma mitigação em prol de interesse público.

O que se deve questionar é onde reside tal interesse público. E a resposta vem da própria natureza jurídica do fenômeno criminal. O direito penal é ramo do direito público, porque o crime é fato de tal reprovabilidade social que importa (e lesa) a toda a sociedade, gerando, suas constatação e reprimenda, um legítimo interesse público. Os processos criminais (e mesmo a fase inquisitorialpolicial) são públicos, com as poucas exceções das chamadas ações penais privadas (intentadas mediante queixa-crime). O Estado, representado pelo órgão do Ministério Público é o titular da ação penal pública, representando a sociedade lesada pelo cometimento do crime, pela quebra da ordem social com a prática do fato típico tido como criminoso.

Neste tema a envolver o interesse público sobre os fatos criminosos, aderimos com prazer à lição precisa e erudita de Costa Andrade ${ }^{68}$, para quem: "o crime não pertence à esfera da privacidade/intimidade, estando sua investigação e divulgação abertas ao exercício da liberdade de imprensa". Reforça o autor que entender de outra forma não seria compatível com o sentido e a função do direito penal num Estado Democrático de Direito. Para ele "estando o direito penal (exclusivamente) vocacionado para a tutela dos bens jurídicos fundamentais da comunidade e da pessoa, a sua afronta - s.c., o crime - releva naturalmente da conflitualidade radical entre o indivíduo e a sociedade. $E$ reveste-se de um interesse público tão evidente como incontornável".

Em continuidade, segue o autor mencionando as diferentes espécies de casos e circunstâncias que, de maneira privilegiada, devem ocasionar a mitigação de aspectos de alguns direitos da personalidade das pessoas envolvidas:

\begin{abstract}
o que fica dito para o crime, em geral, vale natural e privilegiadamente para os tipos de criminalidade que mais abalam e perturbam a comunidade ou que nela despertam um mais agudo e legítimo interesse. Como sucederá, por exemplo, com o crime violento e organizado, o terrorismo, a criminalidade de White-collar (infracções contra a economia, o fisco, a saúde pública, o ambiente, etc.) ou as plúrimas manifestações de corrupção e de utilização indevida de fundos públicos. Não relevando da privacidade/intimidade dos seus agentes, estes factos constituem matéria normal e legítima de investigação jornalística e de notícia. Se o fizer, como se espera que o faça, o jornalista não incorrerá em responsabilidade penal pelo crime de Devassa da vida privada (art. $192^{\circ}$ ) nem se verá privado do direito de prova da verdade dos factos nos termos do $n^{\circ} 3$ do artigo $180^{\circ}$ do Código Penal. ${ }^{69}$
\end{abstract}

Ex positis, é exangue de dúvidas o entendimento de que a pessoa que se envolve em fatos dessa natureza (qualquer fato delituoso), coloca-se em situação que suscita legítimo interesse público e não mera curiosidade popular, havendo justificativa para que aspectos de alguns de seus direitos da personalidade passem a ter um limite protetivo de menor amplitude, ou seja, passem a ser mais permeáveis à invasão de terceiros. O acusado do cometimento de crime (em menor grau) e o condenado pela prática de crime (em maior grau), ambos terão seus atos sindicados pelas autoridades, o que implica alguma devassa da vida privada e até de aspectos da intimidade. 1) Detalhes de suas

68 ANDRADE, Manuel da Costa. Liberdade de imprensa e inviolabilidade pessoal. Uma perspectiva jurídicocriminal. Coimbra: Coimbra Editora, 1996. p. 250.

69 Idem. p. 252. 
condutas serão descortinados aos olhos do público, situação que pode revelar fatos desabonadores de seu caráter e atingir-Ihes a honra objetiva (ataque que terá a licitude garantida em ponderação com o interesse público legítimo de se conhecer o ataque à ordem social cometido por quem delinquiu). 2) Pormenores da vida (ou de segmento temporal dela) do criminoso ou do acusado de crime, serão revelados durante a investigação dos fatos e isto será feito em detrimento da privacidade (imagem, vida privada e até intimidade) daquele, sem que ele possa se opor, dado que há o legítimo interesse em se conhecer a verdade sobre os fatos tidos como criminosos e, portanto, lesivos a toda a sociedade.

Deve ficar claro, entretanto, que tais avanços sociais sobre aspectos de alguns dos direitos da personalidade dos acusados ou condenados pela prática de crime, não querem dizer, de forma alguma, que Ihes foram estes últimos suprimidos, ou que, como uma espécie de pena acessória, se deva diminuir-Ihes a dignidade pessoal.

A mitigação da proteção a alguns aspectos de alguns dos direitos da personalidade é um dano colateral e não um efeito pretendido ou desejado. É algo que se suportará - por inevitável - em nome do interesse público de reprimenda, prevenção e publicidade quanto aos comportamentos criminosos.

Diz Paulo José da Costa Junior, em seu "O Direito de Estar Só"70, que é "lícita, portanto, a publicação da fotografia do evadido de cárcere ou manicômio, de pessoa procurada pela Polícia ou pela Justiça, de pessoa perdida". Adverte o autor, no entanto, que nada justifica estampar, por exemplo, o rosto de quem, condenado, já tivesse cumprido sua pena, pois "não merece tê-la ainda agravada, pela sua divulgação desnecessária".

A redução das garantias protetivas desses particulares aspectos de alguns dos direitos da personalidade dos envolvidos em crimes deve dar-se da forma menos onerosa para seus titulares, de forma que o interesse público seja contemplado, sempre, no entanto, com a menor ingerência possível no campo da dignidade pessoal do indivíduo.

A própria Lei das Execuções Penais, Lei n 7.210 de 11 de julho de 1984, traz em seu art. $3^{\circ}$, balizas a serem observadas com relação aos direitos do apenado que Ihe serão subtraídos ${ }^{71}$.

Vê-se, com clareza meridiana que apenas os direitos retirados do apenado pela sentença (o direito de ir e vir, por exemplo, no caso de pena privativa de liberdade) ou pela lei (como a perda reflexa de alguns direitos políticos e outras penas acessórias) é que são sujeitos ao sacrifício. Todo o restante do arcabouço de direitos da pessoa envolvida em fato criminoso resta íntegro, com a exceção das mitigações próprias da condição de apenado (alguma privacidade se perderá num regime prisional, por certo e inevitavelmente) e daquelas informadas pelo interesse público, principalmente pela publicidade a envolver as questões atinentes à matéria.

Um outro fenômeno contemporâneo a investir diariamente contra direitos da personalidade das pessoas envolvidas - ou supostamente envolvidas - com fatos delituosos, são os programas

\footnotetext{
70 COSTA JUNIOR, Paulo José da. O direito de estar só. 2. ed. São Paulo: RT, 1995. p. 46.

${ }^{71}$ Art. $3^{\circ}$. Ao condenado e ao internado serão assegurados todos os direitos não atingidos pela sentença ou pela lei.

Parágrafo único. Não haverá qualquer distinção de natureza racial, social, religiosa ou política.
} 
televisivos noticiosos, de apelo muito popular e temática policial. Eles são vários e seus apresentadores logo se destacam como espécie de vingadores da sociedade (não raro candidatam-se ou são lembrados como candidatos a cargos eletivos de relevância) exatamente porque vociferam os maiores impropérios contra pessoas às vezes meramente cogitadas como envolvidas em crimes.

Imagens pessoais são submetidas à hiperexposição desses programas de enorme audiência e as honras das pessoas ali retratadas são, em regra, enxovalhadas ao vivo e em rede nacional. Ao depois, se verificada a inocência do acusado, nunca se teve notícia de uma retratação ao vivo e com a mesma ênfase.

Assim, com relação à mitigação, em benefício do interesse público, da proteção de aspectos de alguns dos direitos da personalidade daqueles que envolvidos em fatos criminosos, parece-nos importante destacar três situações excepcionais em que o cuidado deve ser redobrado: a) as situações de abuso, quando a mitigação passa do mínimo necessário à contemplação do interesse público com a manutenção máxima possível da dignidade pessoal do envolvido (não se deve jamais esquecer que, quando em colisão, os princípios constitucionais não devem aniquilar um ao outro, devem preservar ambos o núcleo essencial de seu conteúdo, independentemente de qual deles prepondere naquela situação fática); b) as situações em que ainda vigente a presunção de não culpabilidade (ou presunção de inocência), ou seja, enquanto não transitada em julgado a sentença penal condenatória, ocasião que marca o momento em que alguém pode ser considerado culpado pela prática de um crime (conforme a dicção do art. $5^{\circ}$, LVII da Constituição Federal) e c) as situações em que incide o direito ao esquecimento, como vimos em item anterior, mormente quando cumprida a pena recebida pelo condenado e este, tendo em vista sua necessária ressocialização, tem direito a não ver mais desvelados os fatos relativos à sua condenação pretérita.

Em que pese já tenhamos tratado do direito ao esquecimento, no que respeita, especificamente, ao caso dos condenados que cumpriram pena (item "c" supra), vale aqui, trazer, uma vez mais, a sempre precisa lição de Costa Andrade, verbis:

Por um lado, invoca-se a erosão da dimensão de publicidade provocada pelo decurso do tempo. Também aqui se confirmará de algum modo a conhecida intuição de Ovídio - tempus edax rerum! - a que alguns penalistas expressamente se acolhem.

Em segundo lugar e sobretudo, faz-se valer a prevalência do direito à ressocialização do condenado que cumpriu a pena. [...] Para se poupar ao recluso - e, afinal, também à sociedade - o perigo de um pelourinho público permanentemente reactualizado. Com todo o seu cortejo de consequências indesejáveis - que passam pelo avivar constante de estigma e por mecanismos como a interpretação retrospectiva, a distância social, a diminuição de oportunidades legítimas... em definitivo: pela assunção irreversível de uma carreira delinquente - e que a moderna criminologia tem posto abundante e fundadamente em evidência. ${ }^{72}$

\section{CONCLUSÃO}

Assim, a conclusão a que se chega é no sentido da plena reparabilidade dos danos causados pelo abuso no exercício das liberdades comunicativas, não sendo estas uma classe preferencial prima

72 ANDRADE, Manuel da Costa. Liberdade de imprensa e inviolabilidade pessoal - Uma perspectiva jurídicocriminal. Coimbra: Coimbra Editora, 1996. p. 254-255. 
facie de garantias individuais. Quando resulte da ponderação entre os valores fundamentais em colisão, que deva ceder passo a liberdade de expressão, em face da preponderância no caso concreto dos direitos da personalidade vulnerados pelo seu abuso, ter-se-á o ilício a causar dano e ensejar sua reparação.

É exangue de dúvida o fato de que a ponderação exige o esvaziamento prévio dos pratos da balança, não havendo falar-se em princípio aprioristicamente preponderante em tese. As liberdades comunicativas são um princípio de suma importância - garantidor da equidade e da regra democrática - mas também o são os princípios constitucionais protetivos da honra, da imagem, da vida privada e da intimidade.

A ponderação entre essas duas classes de princípios constitucionais deve dar-se com vistas ao caso concreto e sem qualquer diferença de peso entre os polos colidentes. Só assim se garantirá a mais justa apreciação das dimensões de peso dos valores - para usar a terminologia adotada por Dworkin - em vista da casuística, determinando qual deles deve ter sua aplicação mitigada em benefício de uma preponderância do outro naquela hipótese fática.

As liberdades comunicativas não guardam relação com a liberdade do homem na natureza, com a franquia absoluta dos comportamentos, desde que invocada a prerrogativa de dizer o que se pensa ou de manifestar um produto de seu espírito. As liberdades comunicativas são, sim, limitadas por todo um arcabouço de direitos alheios. Para lembrar o exemplo clássico da literatura sobre liberdade de expressão: em que pese as pessoas sejam livres para manifestar o seu pensamento, a ninguém é dado gritar "fogo!" num auditório lotado, sem que haja um incêndio, provocando tumulto, pisoteio e danos à incolumidade física e psíquica de todos os demais. Em situação de abuso no exercício das liberdades comunicativas - determinado após a necessária ponderação - entra em cena o sistema de regras da Responsabilidade Civil de forma a indenizar ou mitigar os danos dele decorrentes.

\section{REFERÊNCIAS}

ALEXY, Robert. Teoría de los derechos fundamentales. Trad. Ernesto Garzón Valdéz. Madrid: Centro de Estudios Constitucionales, 1993.

ALEXY, Robert. Teoria dos direitos fundamentais. 2. ed., Tradução de Virgílio Afonso da Silva. São Paulo: Malheiros, 2014.

ANDRADE, Manuel da Costa. Liberdade de imprensa e inviolabilidade pessoal: uma perspectiva jurídico-criminal. Coimbra: Coimbra Editora, 1996.

ASCENSÃO, José de Oliveira. O direito: introdução e teoria geral - uma perspectiva luso-brasileira. Lisboa: Fundação Calouste Gulbenkian, 1977.

ÁVILA, Humberto. Teoria dos princípios. 16. ed. São Paulo: Malheiros, 2015.

BENTIVEGNA, Carlos Frederico Barbosa. Liberdade de Expressão, honra, imagem e privacidade. Os limites entre o lícito e o ilícito. São Paulo: Manole, 2019, p. 221

BARROSO, Luís Roberto. A nova interpretação constitucional: ponderação, direitos fundamentais e relações privadas. 3. ed. Rio de Janeiro: Renovar, 2008. 
CAPELO DE SOUSA, Rabindranath Valentino Aleixo. O direito geral de personalidade. Coimbra: Coimbra Editora, 1995.

CANOTILHO, J.J. Gomes. Direito constitucional. 5. ed. Coimbra: Almedina, 1992.

CANOTILHO, J. J. Gomes. Direito constitucional e teoria da constituição. 7. ed. Coimbra: Almedina, 2003.

CANOTILHO, J. J. Gomes; MOREIRA, Vital. Constituição da república portuguesa anotada. vol 1. Edição conjunta de Coimbra Editora (Coimbra) e Revista dos Tribunais (São Paulo), 2007.

CORDEIRO, António Menezes. Tratado de direito civil português. Vol I, parte geral. Tomo III. Coimbra: Almedina, 2004.

COSTA JÚNIOR, Paulo José da. O direito de estar só - Tutela penal da intimidade. 2. ed. São Paulo: RT, 1995.

CRIVELLI, Ivana Có Galdino. Intimidade e privacidade na era da informação. In: CORREIA, Atalá; CAPUCHO, Fábio Jun (coords). Direitos da personalidade. A contribuição de Silmara J. A. Chinellato. Barueri: Manole, 2019.

DWORKIN, Ronald. Levando os direitos a sério. Tradução de Nelson Boeira. São Paulo: Martins Fontes, 2002.

FARIAS, Edilsom Pereira de. Colisão de direitos. A honra, a intimidade, a vida privada e a imagem versus a liberdade de expressão e informação. Porto Alegre: Sergio Antonio Fabris Editor, 1996.

FERNANDES, André de Godoy. Meios de comunicação social no Brasil: promoção do pluralismo, direito concorrencial e regulação. Tese de Doutorado sob orientação do Professor Doutor Calixto Salomão Filho, defendida perante a Faculdade de Direito da Universidade de São Paulo. São Paulo, 2009.

FERRARA, Francesco, Tratatto di diritto civile italiano. Roma: Atheneum, 1921.

FERREIRA, Pinto. Comentários à Constituição brasileira. São Paulo: Saraiva, 1989.

FRANCESCHELLI, Bruno. Diritto alla riservatezza. Napoli: Casa Editrice Dott. Eugenio Jovene, 1960.

GODOY, Claudio Luiz Bueno de. A liberdade de imprensa e os direitos da Personalidade. 3. ed., São Paulo: Atlas, 2015.

KARPEN, Ulrich. The Constitution of the Federal Republic of Germany, apud MENDES, Gilmar Ferreira e BRANCO, Paulo Gustavo Gonet, Op. cit. p

LÉCUYER, Guillaume. Liberté d'expression et responsabilité - Étude de droit privé. Thèse pour le doctorat en droit de l'Université Panthéon-Sorbonne (Paris I). Paris: LGDJ, 2004.

MAZUR, Maurício. A dicotomia entre os direitos de personalidade e os direitos fundamentais. In: MIRANDA, Jorge; RODRIGUES JUNIOR, Otávio Luiz; FRUET, Gustavo Bonato (orgs.). Direitos da Personalidade. São Paulo: Atlas, 2012.

MENDES, Gilmar Ferreira. Colisão de direitos fundamentais: liberdade de expressão e de comunicação e direito à honra e à imagem. in Informativo Consulex, ano VII, vol. 43, Brasília, 1993.

MENDES, Gilmar Ferreira; BRANCO, Paulo Gustavo Gonet. Curso de direito constitucional. 11. ed. São Paulo: Saraiva, 2016. 
MIRANDA, Jorge. Manual de direito constitucional: direitos fundamentais. Tomo IV. 2. ed. Coimbra: Coimbra Editora, 1993.

MIRANDA, Jorge; RODRIGUES JUNIOR, Otávio Luiz e FRUET, Gustavo Bonato. Principais problemas dos direitos da personalidade e estado-da-arte da matéria no direito comparado. In: MIRANDA, Jorge; RODRIGUES JUNIOR, Otávio Luiz e FRUET, Gustavo Bonato (orgs.). Direitos da personalidade. São Paulo: Ed. Atlas. 2012.

MORATO, Antonio Carlos; DE CICCO, Maria Cristina. Direito ao esquecimento: luzes e sombras. In: SILVEIRA, Renato de Mello Jorge; GOMES, Mariângela Gama de Magalhães (orgs). Estudos em homenagem a Ivette Senise Ferreira. São Paulo: LiberArs, 2015.

OST, François. O tempo do direito. Trad. Élcio Fernandes, Bauru: EDUSC, 2005.

POTIGUAR, Alex. Liberdade de expressão e o discurso de ódio: a luta pelo reconhecimento da igualdade como direito à diferença. Brasília: Ed. Consulex, 2012.

PIMENTA BUENO, José Antônio. Direito publico brazileiro e analyse da constituição do imperio. Rio de Janeiro: Typ. Imp. e Const. de J. Villeneuve e C., 1857.

RIGAMONTE, Paulo Arthur Germano; SILVEIRA, Daniel Barile da. Liberdade de expressão e humor. Curitiba: Juruá, 2018.

RODRIGUES JR., Otavio Luiz. Direito civil contemporâneo. Estatuto epistemológico, constituição e direitos fundamentais. Rio de Janeiro: Forense Universitária, 2019.

SARMENTO, Daniel. A ponderação de interesses na constituição federal. Rio de Janeiro: Lumen Juris, 2002.

SILVA JUNIOR, Alcides Leopoldo e. A pessoa pública e o seu direito de imagem. São Paulo: Juarez de Oliveira, 2002.

Recebido: 25.03.2021

Aprovado: 23.06 .2021

Como citar: BENTIVEGNA, Carlos Frederico Barbosa. Responsabilidade civil e o exercício das liberdades comunicativas. Revista IBERC, Belo Horizonte, v. 4, n. 2, p. 79-111, maio/ago. 2021.

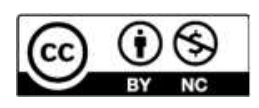

